\title{
MELEPASI BELENGGU KONTRAK KOMPENI: REFLEKSI HUBUNGAN \\ BUTON-BELANDA DALAM WARKAH \\ VEREENIGDE OOSTINDISCHE COMPAGNIE KEPADA SULTAN AZIMUDDIN
}

\section{(Breaking the Shackles of Kompeni Contracts: A Reflection of Butonese-Dutch Relations in a Letter from Vereenigde Oostindische Compagnie to Sultan Azimuddin)}

Suryadi

s.suryadi@hum.leidenuniv.nl

Leiden Institute for Area Studies (LIAS), Leiden University. Felo tamu Institut Antarabangsa Tamadun Islam dan Dunia Melayu (ISTAC) UIAM.

Published online: 3 December 2018

To cite: Suryadi S. (2018). Melepasi belenggu kontrak kompeni: Refleksi hubungan Buton-Belanda dalam warkah VOC kepada Sultan Azimuddin. Malay Literature 31(2), 227 - 262.

\begin{abstract}
Abstrak
Kesultanan Buton yang terletak di jazirah tenggara Pulau Sulawesi adalah sebuah kerajaan Islam bercorak kepulauan yang sudah wujud lama sebelum kedatangan kuasa Eropah di Dunia Melayu-Nusantara. Secara politik, Kesultanan Buton selalu berasa terancam kerana persaingan dan peluasan wilayah dan politik antara dua kerajaan tetangganya yang besar dan kuat, iaitu Gowa dan Ternate. Oleh itu, Sultan Buton ke-4 Dayanu Ikhsanuddin atau La Elangi (1578 - 1615) mengikrarkan "persekutuan abadi" dengan Vereenigde Oostindische Compagnie (VOC) pada 5 Januari 1613. Inti perjanjian itu adalah bahawa VOC akan membantu Buton apabila diserang oleh musuhmusuhnya tapi dengan beberapa syarat yang harus dipenuhi oleh Buton. Perjanjian itu telah "mengikat" sultan Buton berikutnya. Makalah ini membahaskan sepucuk warkah sepanjang 13 halaman
\end{abstract}


daripada Gabenor VOC di Makassar, mewakili Gabenor Jeneral VOC di Batavia, yang dikirimkan kepada Sultan Buton ke-25, Azimuddin atau La Masalumu (1788 - 1791), bertarikh 25 Februari 1791 yang versi digitalnya dimiliki oleh The British Library dengan kod EAP212/6/3 dan naskhah aslinya tersimpan di Buton, yang berada dalam koleksi Abdul Mulku Zahari di Baubau. Makalah ini membahaskan isinya dan menghubungkaitkan dengan latar sejarah sosiopolitik Kesultanan Buton.

Kata kunci: Buton, warkah, EAP212/7/3, The British Library, VOC, kontrak politik, Sultan Azimuddin, kolonialisme

\begin{abstract}
The Sultanate of Buton, situated in the south-eastern peninsula of Sulawesi Island, was an archipelagic Islamic kingdom that has long been existed before the arrival of European power in the MalayNusantara world. Politically, the Sultanate of Buton, that was relatively small, always feels threatened because of the territorial expansion and political rivalry between its large and powerful neighboring kingdoms: Gowa and Ternate. Therefore, the 4th Butonese sultan Dayanu Ikhsanuddin or La Elangi (1578 - 1615) pledged "everlasting alliance" with the Vereenigde Oostindische Compagnie (VOC) on 5 January 1613. The essence of the treaty was that the VOC would help Buton if attacked by the enemies, but with some requirements that must be met by Buton. The treaty had "bundled" the next Buton sultans. This paper discusses a 13-pages letter sent by the VOC's Governor in Makassar, represented the VOC's Governor General in Batavia, to the 25th Butonese sultan Azimuddin or La Masalumu (1788-1791), dated on 25 February 1791, which its digital version owned by The British Library under code EAP212/6/3 and its original manuscript hold in Abdul Mulku Zahari's collection in Baubau, Buton. This paper provides the Roman transliteration of the letter, discusses its contents and relates them to the socio-political historical background of the sultanate of Buton of that period.
\end{abstract}

Keywords: Buton, letter, EAP212/7/3, The British Library, VOC, political contract, Sultan Azimuddin, colonialism 


\section{PENDAHULUAN}

Warkah Melayu merupakan korpus terbesar dengan jumlah terbanyak dari segi bilangan naskhah Melayu yang disimpan di pelbagai perpustakaan di dunia yang memiliki koleksi Manuskrip Melayu, sama ada di Eropah mahupun di Nusantara. Korpus ini mewakili pelbagai negara di Asia Tenggara yang pada zaman kolonial berada di bawah kekuasaan Belanda dan Inggeris. Kebanyakan warkah Melayu tersebut merupakan bukti korespondensi antara raja-raja di wilayah Melayu-Nusantara dengan penguasa kolonial dari pelbagai aras atau tingkat, terutama dengan para Gabenor Jeneral Inggeris di Singapura dan para Gabenor Jeneral Hindia Belanda di Batavia (sekarang: Jakarta). Selain warkah yang termasuk dalam kategori royal letters, ada pula warkah yang merupakan korespondensi antara orang biasa, atau antara rakyat umum. Warkah Melayu lama itu merupakan dokumen autentik yang bukan saja mewakili kontak dan kontrak politik antara kerajaan di wilayah Melayu Nusantara dengan penguasa kolonial Belanda dan Inggeris, tetapi juga merupakan sumber penting untuk kajian tentang perkembangan sejarah bahasa Melayu. Banyak kajian selain dari perspektif sejarah dan linguistik telah pula dilakukan oleh para sarjana terhadap warkah Melayu klasik seperti iluminasi, cap mohor, dan seni kaligrafi. Artikel ini membahaskan warkah dari Kerajaan Buton dari perspektif sejarah dari segi hubungan politik antara kerajaan lokal yang terletak di jazirah selatan Pulau Sulawesi itu dengan VOC (Vereenigde Oostindische Compagnie ) pada abad ke-19.

\section{WARKAH KERAJAAN BUTON}

Makalah ini membahaskan sebuah naskhah Buton yang tersimpan dalam koleksi Abdul Mulku Zahari di Baubau, Buton. Dalam Katalog Naskah Buton Koleksi Abdul Mulku Zahari karya Achadiati Ikram, Tjiptaningrum Fuad Hassan, dan Dewaki Kramadibrata (2001, pp. 238 - 239) diberikan kod: SR/45/AMZ (Rajah 1). Projek pendigitalan naskhah Buton ini juga mendigitalkan naskhah dalam koleksi Abdul Mulku Zahari, lihat Rajah 1.

Naskhah ini ialah warkah kompeni Belanda kepada Sultan Buton Azimuddin, dan telah didigitalkan melalui Projek "EAP212: Locating, documenting and digitising: Preserving the endangered manuscripts of the Legacy of the Sultanate of Buton, South-Eastern Sulawesi Province, Indonesia (2008 - 2010)". ${ }^{1}$ Projek ini berada di bawah seliaan penyelidik sebagai principal applicant yang dibiayai oleh The British Library. Dalam koleksi The British Library yang dapat diakses secara dalam talian, naskhah 


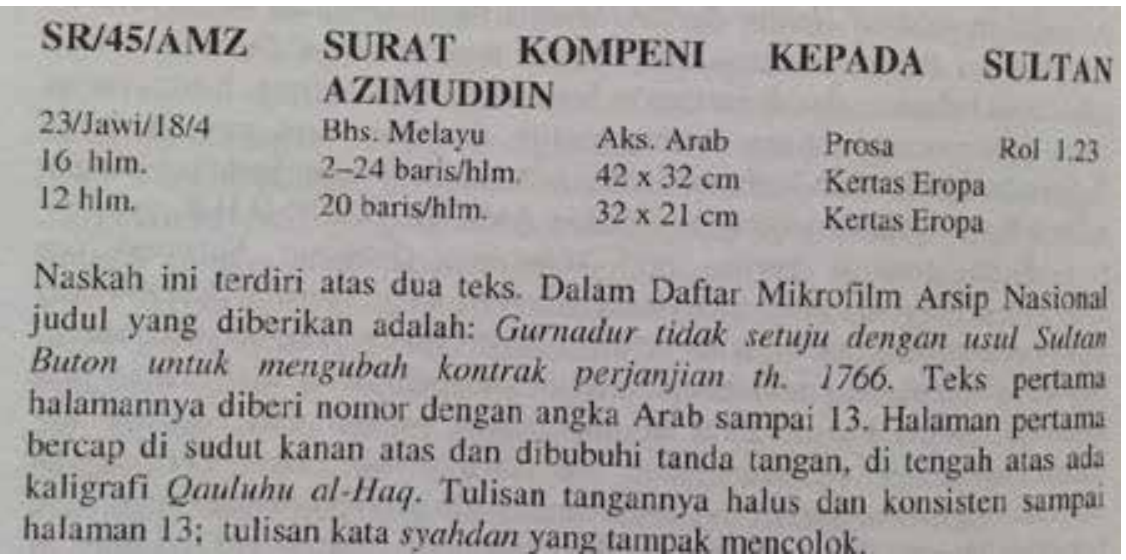

Rajah 1 Kod dan maklumat kodikologis warkah yang dibahaskan ini mengikut deskripsi yang dibuat oleh Achadiati Ikram, Tjiptaningrum Fuad Hassan, dan Dewaki Kramadibrata (2001, p. 238).

ini, yang tercatat dengan kod nombor: EAP212/6/3: Surat Kompeni kepada Sultan Azimuddin. ${ }^{2}$ EAP212/6/3, hanyalah salah satu dari banyak warkah antara Keraton Kesultanan Buton dan Belanda yang tersimpan di beberapa tempat penyimpanan naskhah milik perseorangan yang ada di Buton, selain di luar negeri, seperti di Leiden dan St. Petersburg (Suryadi, 2007a,b; Suryadi, 2010; Katkova, 2011). Achadiati Ikram, Tjiptaningrum Fuad Hassan dan Dewaki Kramadibrata (2001, pp. 10 - 11) mengatakan bahawa korpus ini mencakupi "surat peribadi mahupun rasmi, seperti surat-menyurat kenegaraan dan surat antara pejabat mengenai soal pemerintahan, [s] urat daripada VOC kepada Sultan [bahagian yang paling menarik dari korpus ini], [s]urat-surat pengangkatan, surat rekomendasi, [dan] surat ketetapan." EAP212/6/3 berisi pelbagai tanggapan, kritik, dan peringatan Kompeni Belanda (VOC) kepada Istana Wolio (Istana Sultan Buton).

Makalah ini cuba mengenal pasti isu penting yang terkandung dalam warkah yang dapat menggambarkan hubungan politik dinamik antara Kesultanan Buton dengan Belanda pada akhir kurun ke-18. Untuk itu, dalam makalah ini akan dijelaskan konteks sejarah warkah ini.

EAP212/6/3 unik kerana merupakan satu dari sedikit warkah korespondensi antara Kompeni dengan raja-raja setempat yang berasal dari (atau dikirimkan oleh) pihak Kompeni sendiri yang masih tersisa sekarang, dan berada di tangan penyimpan naskhah lokal yang ada di Buton. Selama ini, yang sudah banyak dikaji oleh para pakar persuratan Melayu klasik, 
termasuk dalam konteks pernaskhahan Buton ialah warkah daripada pihak sebaliknya, iaitu warkah daripada raja-raja di Nusantara kepada Kompeni. ${ }^{3}$ Oleh itu, kita dapat menduga bahawa isi EAP212/6/3 dapat dianggap mewakili sikap atau sifat penjajah (orang Belanda) dan pandangan mereka terhadap Buton.

Warkah Buton, sama ada yang dikirimkan kepada Kompeni Belanda atau sebaliknya, pada umumnya ditulis dalam aksara Arab-Melayu (Jawi), mengandungi maklumat sejarah yang tak kurang nilainya berbanding dokumen yang ditulis oleh orang Eropah. ${ }^{4}$

\title{
EAP212/6/3: MAKLUMAT KODIKOLOGIS
}

EAP212/6/3 ialah warkah panjang, mengandungi 15 halaman. Ab. Razak et al. (2011, p. 29) bahkan menyebut bahawa warkah ini sebagai "surat sosial yang terpanjang yang pernah" mereka temui sebagai pengkaji naskhah. Akan tetapi dua halaman terakhir sebenarnya ialah dua warkah lain, bukan sebahagian daripada warkah yang pertama. Kedua-duanya menggunakan gaya tulisan yang berbeza pula (lihat Lampiran II).

EAP212/6/3 dikirimkan oleh Gabenor/Pemerintah VOC di Makassar kepada Sultan Buton Azimuddin. Ini dapat dikenal pasti daripada tulisan tangan pada sudut atas halaman pertama warkah ini (lihat ilustrasi), di bawah cap mohor yang berwarna merah (tidak ada inskripsi) yang tertulis: "Maccasjer in het Kasteel Rotterdam den 25e february 17915" dengan tanda tangan Gabenor di bawahnya (lihat Rajah 2).

Seperti dapat dibaca dalam talian online http://eap.bl.uk/database/ overview_item. a4d?catId $=33475 ; \mathrm{r}=24393$, scope dan content naskhah ini adalah sebagai berikut:

\begin{abstract}
European paper: Crowned Shield (Strasbourg lily) (7.0), with J. Honig \& Zoonen, $42 \times 32 \mathrm{~cm}$; 15 pages; comprised roughly of $20-$ 24 lines per page; black ink; Arabic-Malay script; Malay language; no colophon (sic). Article is fragile, riddled with holes, unbound with pages tattered, although writing within is still legible. Content deals with various issues addressed to Sri Sultan Azimuddin of Buton from the Company.
\end{abstract}

Perlu dimaklumkan bahawa halaman dua warkah ini kertasnya berwarna hijau kelabu, agak berbeza dengan halaman yang lain. Nombor halaman muncul kemudian kerana ditambahkan oleh penyimpan atau pembaca warkah ini. 
MALAY LITERATURE VOLUME 31 NUMBER 2 DECEMBER 2018

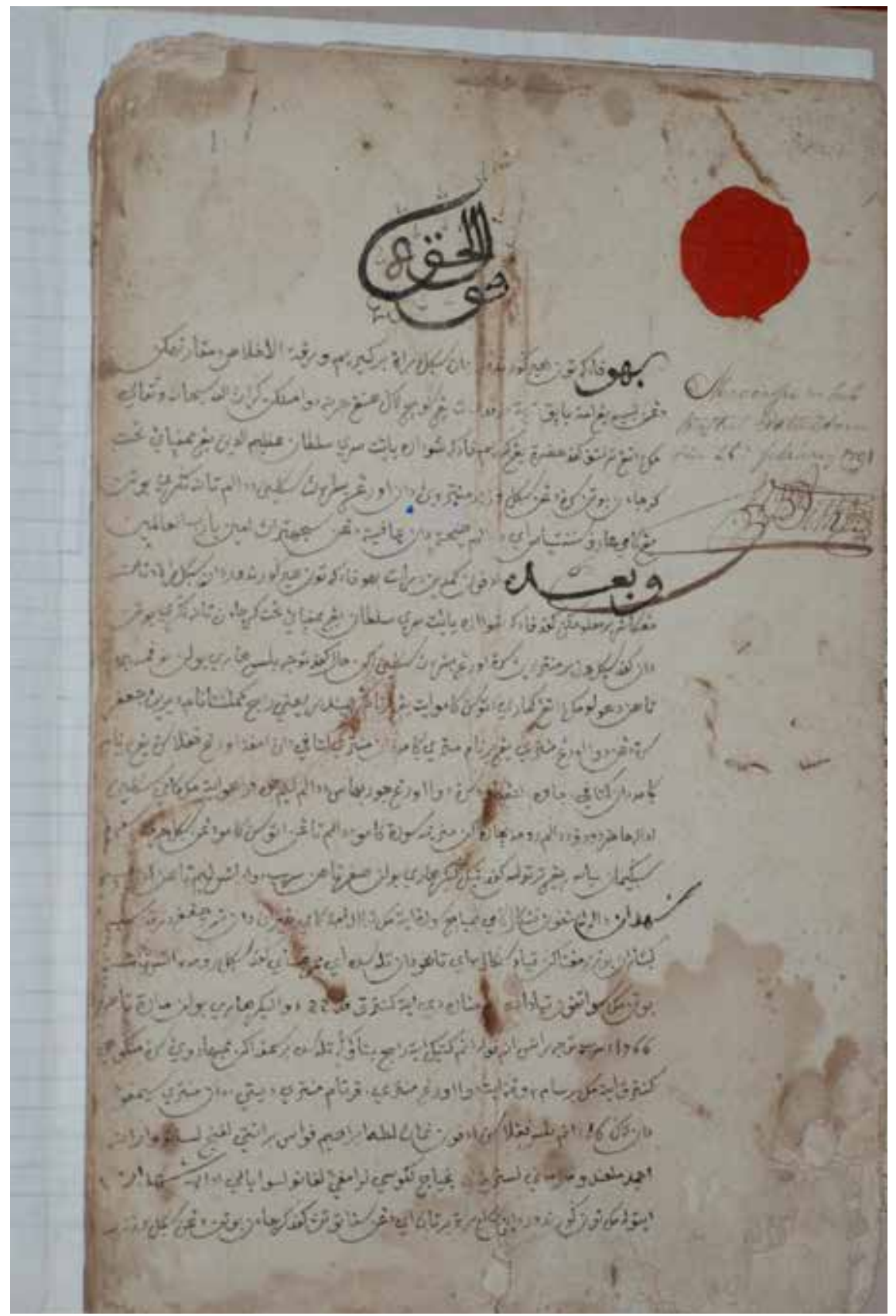

Rajah 2 EAP212/6/3, halaman 1 
Seperti telah disebutkan di atas, EAP212/6/3 (atau SR/45/AMZ) terdiri daripada tiga warkah yang berbeza: halaman 1 hingga 13 ialah warkah Kompeni/VOC kepada Sultan Azimuddin, sedangkan halaman 14 dan 15 ialah dua warkah Sultan Buton Dayan Asraruddin (1799 - 1822) kepada Kompeni Belanda, yang tidak lengkap. Jadi, dari segi isi, dua halaman terakhir tidak memiliki sebarang hubungan tekstual dengan tiga belas halaman pertama.

Berkemungkinan besar EAP212/6/3 yang asli ditulis dalam bahasa Belanda, kemudian diterjemahkan ke dalam bahasa Melayu dengan aksara Jawi. ${ }^{6}$ Meskipun dalam tradisi literasi Buton suatu kebiasaan bagi seseorang untuk menulis bahasa Wolio menggunakan aksara Jawi (lihat catatan Van den Berg dalam Cense, 1954, p. 156), namun dalam warkah korespondensi antara Keraton Buton dan Belanda atau sebaliknya, dan juga antara sesama penguasa kerajaan di Nusantara, bahasa Melayulah yang cenderung dipakai kerana fungsinya sebagai lingua franca sudah wujud sebelum kedatangan kuasa orang putih (Eropah) di rantau ini pada kurun ke-16. Mungkin penulisan warkah ini dalam aksara Jawi menggunakan jasa seorang penterjemah Melayu. $^{7}$ Kesan penterjemahan daripada Bahasa Belanda itu cukup terasa setelah kita membaca alih aksara warkah ini (lihat Lampiran I). Bahasanya agak berbelit-belit, yang mungkin kerana mengikut gaya ayat bahasa Belandanya: ayat-ayatnya panjang-panjang dan banyak pengulangan, berbeza dengan warkah yang dikirimkan oleh raja-raja Buton kepada Kompeni yang memiliki ayat yang pada umumnya lebih pendek dan kurang mengandungi pengulangan.

\section{KONTEKS SEJARAH EAP212/6/3}

Sebelum mengenal pasti kandungan EAP212/6/3 dengan lebih lanjut, perlu dijelaskan secara sepintas lalu hubungan Buton dengan Belanda yang menjadi latar sejarah warkah ini. Hubungan rasmi antara para pedagang di bawah bendera VOC (Vereenigde Oostindische Compagnie) dengan Kerajaan Buton, yang terletak di hujung jazirah tenggara pulau Sulawesi (Celebes), ketika diperintah oleh Sultan Dayanu Ikhsanuddin atau La Elangi $(1578-1615) .{ }^{8}$ Namun begitu, lama sebelum VOC hadir di Kepulauan Nusantara bahagian timur, Buton sudah berstatus sebagai sebuah kerajaan maritim. Kerajaan ini berada di tengah-tengah perlumbaan atau perseteruan antara dua kerajaan tetangganya yang kuat, iaitu Gowa (atau Gowa-Talloq) dan Ternate.

Secara geografi Buton terletak di laluan pelayaran yang strategik antara Jawa dengan Sulawesi dan Maluku Utara, yang merupakan salah 
satu laluan tradisi VOC to Spice Islands (ke pulau rempah), meminjam kata-kata Robert Parthesius (2010, p. 143). Sejak mula, VOC menggunakan laluan strategik ini, walaupun kadang-kadang sangat berbahaya kerana ancaman angin musim yang mengganggu pelayaran kapal dagang dari Jawa (Batavia) ke Ternate atau sebaliknya. Sebelum VOC berjaya menancapkan pengaruhnya di perairan Nusantara bahagian timur melalui Perjanjian Bungaya (18 November 1667), Kesultanan Buton sudah berada dalam pengaruh Kerajaan Ternate (Susanto, Ohorella, dan Said D., 1996, p. 65). Akan tetapi, Kerajaan Gowa, lebih-lebih lagi semasa dipimpin oleh Sultan Hasanuddin (1653 - 1669), terus berusaha meluaskan pengaruhnya, tidak terkecuali ke wilayah pulau-pulau yang dianggap oleh Buton sebagai wilayah kekuasaannya, seperti Kabaena dan lain-lain. Kehadiran VOC di wilayah ini telah meningkatkan persaingan politik antara kedua-dua kerajaan itu. ${ }^{9}$ Posisi Buton dapat diibaratkan seperti pelanduk yang terjepit dalam perkelahian dua ekor gajah, yang kemudian dicampur tangan pula oleh VOC. Berkalikali pulau-pulau yang dianggap oleh Buton sebagai wilayah kekuasaannya dirampas oleh Ternate dan Gowa (Susanto, 2010). Orang-orang Makassar, penduduk utama dan pendukung Kerajaan Gowa, sangat berpengaruh di Buton, seperti yang berlaku dalam peristiwa rompakan terhadap kapal VOC Rustenwerk (Rusten en Werk) di teluk Baubau pada tahun 1752 (lihat: Mourik, c.1752) dan beberapa peristiwa lain.

Pada 5 Januari 1613, Commandeur VOC Applonius Scotte (atau Schotte), mewakili Gabenor Jeneral VOC yang pertama, Pieter Both $(1610-1614)$, mengikat kontrak perjanjian dengan Sultan Dayanu Ikhsanuddin. Orang Buton menyebut perjanjian itu: "janji baana" (Abdul Mulku, 1977, I, p. 68). Secara ringkas, isi perjanjian itu adalah seperti yang berikut (Schoorl et al, 2003, pp. 19 -21; Abdul Mulku [mengutip Ligvoet], 1977, I, pp. 66-68):

Jadual 1 Perjanjian Pieter Both dengan Sultan Dayanu Ikhsanuddin.

\begin{tabular}{|c|c|}
\hline $\begin{array}{c}\text { Yang harus dilakukan VOC untuk } \\
\text { Buton }\end{array}$ & $\begin{array}{l}\text { Yang harus dilakukan Buton untuk } \\
\text { VOC }\end{array}$ \\
\hline $\begin{array}{l}\text { 1. Orang-orang Belanda [VOC] akan } \\
\text { membantu melindungi negeri Buton serta } \\
\text { warganya dari penyerbuan-penyerbuan } \\
\text { musuh. Untuk itu, di pantai akan } \\
\text { dibangun dua buah kubu pertahanan } \\
\text { yang diawaki oleh beberapa orang } \\
\text { Belanda yang dipersenjatai dengan } \\
\text { empat buah meriam }\end{array}$ & $\begin{array}{l}\text { 1. Raja menyatakan telah mengundang } \\
\text { orang-orang Belanda untuk melindungi } \\
\text { Buton serta turut serta dalam perjuangan } \\
\text { melawan musuh-musuhnya, seperti } \\
\text { membantu Raja Ternate, teman Belanda, } \\
\text { yang dengannya Buton juga harus } \\
\text { bersahabat. }^{10}\end{array}$ \\
\hline
\end{tabular}




\begin{tabular}{|c|c|}
\hline $\begin{array}{c}\text { Yang harus dilakukan VOC } \\
\text { untuk Buton }\end{array}$ & Yang harus dilakukan Buton untuk VOC \\
\hline $\begin{array}{l}\text { 2. Scotte berjanji untuk memohon } \\
\text { kepada Gabenor Jeneral agar } \\
\text { mengirim lebih banyak garnisun } \\
\text { serta sebuah kapal atau sebuah } \\
\text { kapal layar ke Buton }\end{array}$ & $\begin{array}{l}\text { 2. Buton berjanji akan membantu Kompeni dalam } \\
\text { misi penaklukan ke Solor. Raja Buton juga berjanji } \\
\text { tidak akan mengizinkan bangsa-bangsa lain } \\
\text { berdagang dan berlalu-lalang di wilayah Buton, } \\
\text { jika ini dinilai akan merugikan Kompeni. Sebagai } \\
\text { pelindung, Kompeni akan memperoleh hak-hak } \\
\text { istimewa }\end{array}$ \\
\hline $\begin{array}{l}\text { 3. Scotte juga berjanji untuk } \\
\text { secepat-cepatnya akan menjadi } \\
\text { penengah antara Buton dan } \\
\text { Makassar dan meminta Makassar } \\
\text { untuk menghentikan semua } \\
\text { permusuhan dengan Buton. }\end{array}$ & $\begin{array}{l}\text { 3. Raja Buton berjanji akan menetapkan harga tetap } \\
\text { untuk barang-barang dagangan dan makanan. Orang } \\
\text { Belanda boleh berdagang di mana-mana dalam } \\
\text { wilayah Kerajaan Buton tanpa harus dipungut } \\
\text { bea apapun. Mereka juga boleh menanam tanam- } \\
\text { tanaman tertentu, asal raja diberi tahu }\end{array}$ \\
\hline \multirow{3}{*}{$\begin{array}{l}\text { 4. Scotte berjanji untuk mendesak } \\
\text { Raja Ternate agar warganya tidak } \\
\text { menimbulkan kesusahan bagi } \\
\text { Raja Buton atau bagi warga Buton } \\
\text { sendiri dan jika ada urusan-urusan, } \\
\text { agar disampaikan secara baik- } \\
\text { baik kepada Raja Buton melalui } \\
\text { para duta atau warkah-warkah } \\
\text { rasmi yang dibubuhi cap mohor } \\
\text { Kerajaan Ternate. }\end{array}$} & $\begin{array}{l}\text { 4. Raja Buton berjanji akan menyuruh warganya } \\
\text { menanam padi untuk kebutuhan [orang Belanda] di } \\
\text { Maluku. }\end{array}$ \\
\hline & $\begin{array}{l}\text { 5. Raja Buton berjanji bahawa serdadu-serdadu } \\
\text { atau pegawai Kompeni yang lain boleh berkahwin } \\
\text { dengan perempuan Buton, juga anak perempuan } \\
\text { bebas/dari kalangan orang biasa, dan mereka harus } \\
\text { diberi tempat tinggal di kerajaan. Para isteri mereka } \\
\text { boleh masuk Kristian. Kompeni boleh membeli } \\
\text { budak laki-laki atau perempuan. }{ }^{11} \text { Jika ada budak } \\
\text { yang melarikan dan mencari perlindungan pada } \\
\text { salah satu pihak, maka ia akan dikembalikan kepada } \\
\text { pemiliknya atau diganti rugi seharga } 10 \text { tanet (kain } \\
\text { Buton) untuk setiap budak. }\end{array}$ \\
\hline & $\begin{array}{l}\text { 6. Raja Buton mengingatkan Kompeni agar } \\
\text { memegang teguh janji abadinya dengan Buton. } \\
\text { Jika pecah perang antara Belanda dengan Banda, } \\
\text { maka Raja Buton akan memanggil saudara laki- } \\
\text { lakinya dan serta warganya yang ada di Banda untuk } \\
\text { kembali ke Buton. }\end{array}$ \\
\hline
\end{tabular}


MALAY LITERATURE VOLUME 31 NUMBER 2 DECEMBER 2018

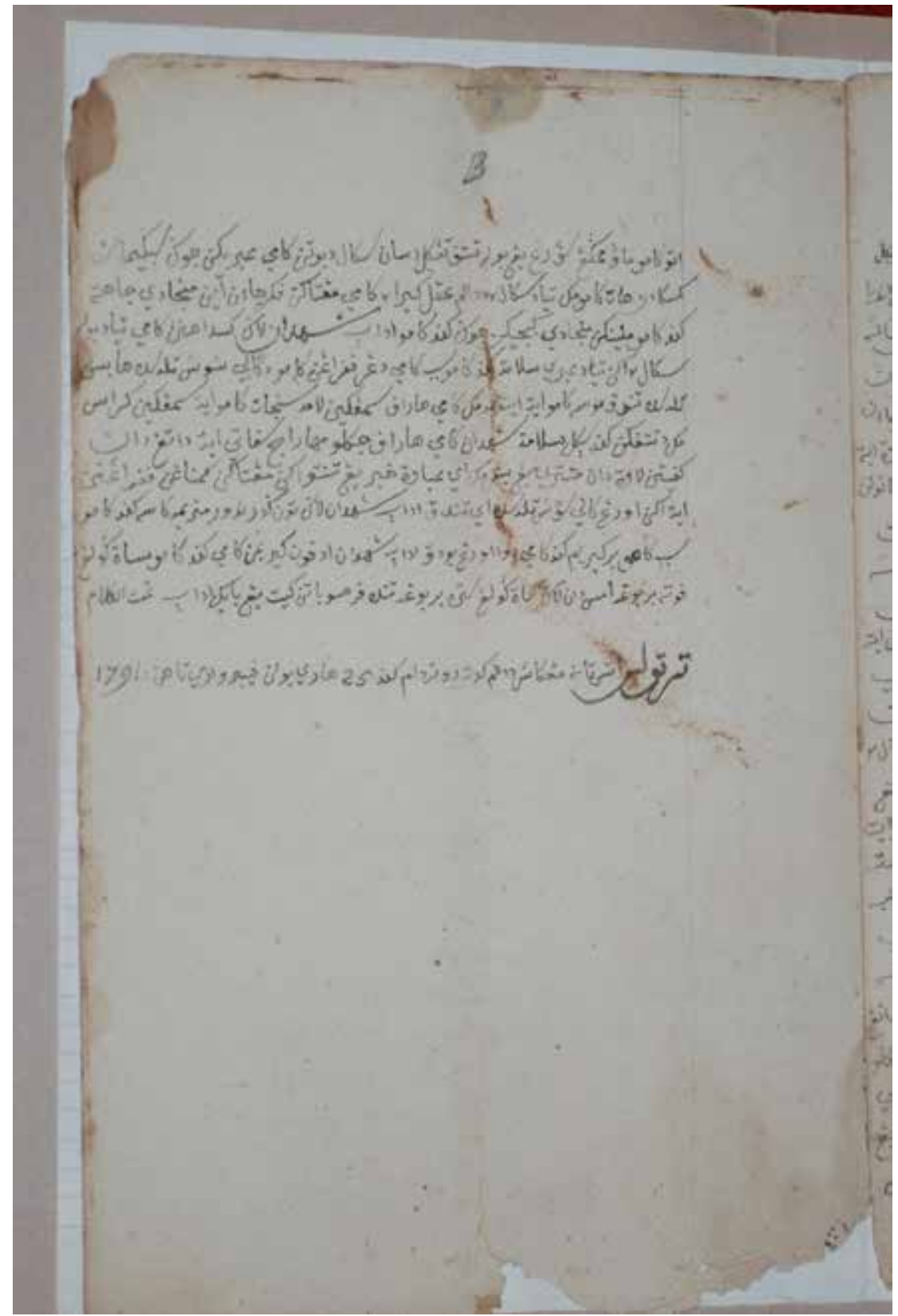

Rajah 3 EAP212/6/3, halaman 13 
Perjanjian Scotte - La Elangi itulah yang mendasari "persekutuan abadi" Buton-Belanda sehingga awal kurun ke-20. Pieter Both sendiri kemudiannya datang ke Buton pada 29 Ogos 1613 (Corpus Diplomaticum, 1907, pp. 104 - 108) untuk "mempersumpahkan" perjanjian itu. Namun begitu, kandungan EAP212/6/3 menyiratkan, bagi kedua-dua belah pihak (Belanda dan Buton), telah beberapa kali melakukan perubahan terhadap isi perjanjian itu, yang kemudian mempengaruhi hubungan politik antara Kerajaan Buton dengan VOC. Sultan Buton berikutnya ada yang tidak bersetuju atau tidak mematuhi pasal-pasal tertentu dalam Kontrak "Persekutuan Abadi" 1613 itu, dan juga kontrak yang dibuat sesudahnya antara Buton dengan VOC. Pihak VOC sendiri juga suka menambah pasal baharu yang menguntungkan pihak mereka. Sebagai contoh, Pieter Both telah menambahkan tiga pasal lagi dalam kontrak yang telah disetujui oleh Scotte dan La Elangi (1613), yang tampaknya dimaksudkan untuk dapat mengawal Buton dengan lebih ketat. Ketiga pasal tambahan itu adalah: (1) Apabila raja (La Elangi/Sultan Dayanu Ikhsanuddin) mangkat, maka anak laki-lakinya yang sah, iaitu Kamaruddin atau Syamsuddin, akan menggantikannya; (2) Semua bangsa asing, kecuali orang Sepanyol dan Portugis [musuh dagang VOC], bebas berdagang di Buton; 3) Perahu [setempat] yang berlayar dari Surabaya ke Makassar yang dicurigai membawa barang-barang [dagangan untuk] musuh, boleh diperiksa VOC dengan dihadiri wakil Raja Buton. Barang-barang itu boleh disita dan hasil sitaan itu boleh dibahagi antara Raja Buton dengan Kompeni (Ligvoet, 1878, p. 33).

Kolofon EAP212/6/3: "Tertulis atas Tanah Mengkasar di dalam kota Rotterdam kepada 25 hari bulan Februari tahun: 1791" (13:11'2) (lihat Rajah 3), jadi 178 tahun setelah perjanjian antara Scotte dengan Sultan Dayanu Ikhsanuddin (La Elangi) dipersumpahkan. Dalam ruang waktu yang cukup panjang itu, tentulah banyak hal yang berubah dalam hubungan antara Buton dengan Belanda, yang dipengaruhi oleh dinamik sosial politik dan ekonomi kawasan Kepulauan Nusantara bahagian timur.

\section{BUTIR-BUTIR PENTING KANDUNGAN EAP212/6/3}

EAP212/6/3 ditulis oleh Gabenor VOC di Makassar sebagai reaksi terhadap warkah Sultan Azimuddin yang dibawa oleh utusan Syahbandar Raja Kamilanta dan para pengiringnya (beberapa orang menteri, pengalasan, dan juru bahasa) yang tiba di Makassar pada "tujuh belas hari bulan November" $1790(1: 8-9) .{ }^{13}$ Isi warkah itu, yang ditulis pada "tiga likur hari bulan Shafar tahun seribu dua ratus lima" (1 November 1790) (1:13), memperlihatkan 
pandangan Raja Buton ketika itu (Sultan Azimuddin) terhadap VOC yang banyak kandungannya dianggap oleh Kompeni tidak sesuai dengan butirbutir kesepakatan dalam kontrak perjanjian antara Buton dengan VOC yang sudah "dipersumpahkan" pada 1766. Gabenor VOC di Makassar lalu menulis EAP212/6/3 yang di dalamnya terkandung tujuh perkara penting seperti yang berikut:

(1) Gabenor "terlalu amat kheran dan tercengang" (1:14) mendapati kenyataan bahawa Sultan Buton yang sekarang, Azimuddin (atau mungkin juga sultan-sultan sebelumnya), mengaku tidak tahumenahu tentang Kontrak Perjanjian antara Buton dengan VOC 1766. Bagaimana mungkin kontrak bertarikh " 22 likur bulan Maret tahun $1766 "(1: 16$ - 17) itu tidak diketahui dan tidak diakui oleh para pembesar Buton sekarang?

(2) Buton belum juga memenuhi segala kewajipannya membayar kerugian atau denda - yang juga sudah diatur dalam Kontrak Perjanjian 1667 dan 1766, dan setelah itu juga sudah ada pula tiga kali peringatan melalui warkah rasmi $(2: 10-12)$ - atas perompakan kapal Rustenwerk (Rust en Werk) pada tahun 1752.

(3) Buton telah "mengeluarkan [memberhentikan] atau mengambil [mengangkat] raja [-raja baru]" (3;14) tanpa sepengetahuan dan tanpa persetujuan Kompeni terlebih dahulu, sebagaimana diatur dalam Pasal 7 dan 8 Kontrak Perjanjian 1766.

(4) Meriam Kompeni yang "sudah beberapa tahun lamanya tinggal [dipakai] di Buton" belum juga "dipulangkan" (6:12) atau dibayarkan harganya dengan budak. Begitu juga dengan "meriam yang tujuh pucuk dan periuk tembaga" (11:10) yang diambil dari sebuah kici (kapal) Kompeni yang pecah di perairan Buton, juga belum dibayar harganya.

(5) Perahu-perahu Buton masih berlayar ke tempat-tempat "yang dilarang oleh Kompeni" (6:20), seperti ke Banda (Bandan) dan Ambon. Menurut undang-undang, para pelakunya boleh dihukum ("dikena $<\mathrm{h}>$ kan hukum batang tubuhnya" [6:23]).

(6) Pelaksanaan untuk "membunuh [memusnahkan]" (12:3) pohon cengkeh dan pala di Buton tidak terlaksana sebagaimana mestinya.

"Kerana banyaklah kelakuan [Buton] yang salah"(5:3), maka 
Kompeni mengancam akan menghukum Buton secara militer, seperti "yang tersebut dalam perkara 9 (Pasal 9)" (9:5) Kontrak Perjanjian 1766.

Itulah antara butir-butir penting dalam EAP212/6/3 yang disampaikan oleh Kompeni (Gabenor VOC di Makassar) kepada Sultan Azimuddin yang memerintah Buton pada ketika itu.

Yang berikut ialah penjelasan mengenai konteks sejarah butir 1: Kontrak Perjanjian Buton dengan VOC Mac 1766. Kontrak ini ditandatangani di markas VOC di Makassar (Ujung Pandang) oleh Raja Bataoga (salah seorang menteri) dan beberapa pembesar Buton, mewakili Sultan Kaimuddin ${ }^{14}$ (La Jampi). EAP212/6/3 menyebut:

Maka telah sudah jadi dibaharui kepada dua likur 22 hari bulan Maret tahun seribu tujuh ratus enam puluh enam 1766: Seperti sebagaimana biasa, maka raja Bataogah itu melakukan dengan segala orang besar2 yang adah bersama2 dengan dia waktu itu membaharui dan bersumpah kepada kontrak itu [...] $(4: 5-8)$.

Sultan Kaimuddin sendiri tidak dapat hadir di Ujung Panjang (Makassar) untuk "mempersumpahkan" kontrak perjanjian itu. Ketidakhadirannya mungkin disebabkan oleh situasi domestik: Buton baru saja pulih daripada masalah politik dalam negerinya yang terlibat dengan kejadian huru-hara yang terjadi di Barata [wilayah autonomi khusus] Muna (Abdul Mulku, 1977, II, pp. 141 - 142). Perjanjian 1766 ialah usaha untuk memperbaharui Perjanjian Persahabatan 25 Jun 1667 yang dikenali sebagai Perjanjian (Cornelis) Speelman - (La) Simbata ${ }^{15}$ (Abdul Mulku, 1977, II, p. 142), seperti disebutkan dengan jelas dalam warkah yang dibahaskan ini:

[M]aka tanah Buton telah sudah menyuruh utusan datang kemari membaharui perjanjian itu dari tahun seribu enam ratus enam puluh tujuh 1667: Maka telah sudah jadi dibaharui kepada dua likur 22 hari bulan Maret tahun seribu tujuh ratus enam puluh enam 1766 (4: 4-6).

Kontrak Perjanjian 1766, terdiri daripada dua bahagian: Bahagian pertama berisi empat pasal mengenai pembayaran budak sebagai ganti rugi atas perosakan kapal Rustenwerk; Bahagian kedua (enam belas pasal) mengenai hubungan kedaulatan dan diplomasi Buton dengan VOC (Susanto, 2010, p. 230). Naskhah kontrak perjanjian ini dalam dua bahasa - Belanda 
dan Melayu - dapat dilihat dalam buku Susanto (2010, pp. 311 - 28). Terdapat banyak pasal yang sifatnya semakin mengikat Buton. Mungkin hal itu yang menyebabkan beberapa raja Buton yang berkuasa pascakontrak perjanjian itu enggan mematuhinya.

Akan tetapi menurut Susanto (2010, pp. 248 - 53), lahirnya Kontrak Perjanjian 1766 berkaitan dengan ketidakstabilan politik dalam negeri Buton pada masa itu.

Sesudah peristiwa penyerangan ke benteng Woliyo (keraton Sultan Buton) [serangan tahun 1755], Sultan Sakiudin mencoba memperbaiki hubungan Buton dengan VOC. Pada Maret 1756, Sinkelaar dan Rijsweber [pegawai tinggi VOC di Makassar] berkunjung ke Buton untuk menawarkan perjanjian baru. Isi pokok [perjanjian itu] terutama mengenai tuntunan (sic) VOC, agar Buton tetap menyerahkan budak sebanyak seribu orang sebagai pembayar ganti rugi [atas perompakan terhadap kapal Rustenwerk; lihat huraian berikut]. Sakiudin meninggal dunia pada tahun 1759[,] kemudian digantikan oleh Rafiudin, pu[t]ra Sultan Safiudin yang turun takhta pada tahun 1702. Ia pun tidak lama memerintah[,] lalu diteruskan oleh Sultan Himayatud[d]in, yang memerintah untuk kedua kalinya pada tahun 1760 - 1763. Pada masa Sultan Kaimudin (M. 1763 - 1788)[,] pengganti Himayatud[d]in, penawaran kontrak oleh VOC akhirnya diterima Buton, maka ditandatanganilah kontrak pada 22 Maret 1766. Penggantian beberapa kali Sultan dalam waktu singkat berarti memperlihatkan ketidakstabilan [politik di] keraton Buton. (Susanto, 2010, pp. $248-249)$.

Penggunaan kata-kata yang bernada mengancam dalam Kontrak Perjanjian itu menggambarkan bahawa tidak ada kuasa mutlak VOC terhadap Buton (Susanto, 2010, p. 250). Oleh itu, VOC terus melakukan pelbagai helah agar tetap dapat mengendalikan Buton secara politik dan ekonomi. Seperti yang tergambar dalam EAP212/6/3. Kekangan Keraton Wolio paling besar ialah berkaitan Pasal 8 Kontrak Perjanjian 1766: ketentuan bahawa setiap penggantian raja atau pengangkatan raja baharu, bahkan juga para pembesar kerajaan, harus diberitahu terlebih dahulu kepada Kompeni dan harus mendapat persetujuan daripada mereka. Hal ini merupakan salah satu butir penting penolakan oleh Sultan Azimuddin dalam warkahnya yang dikirimkan ke Makassar pada bulan Disember 1790 itu (3: 1 - 5; kursif oleh Suryadi): 
Syahdan lagi kami bermaklumkan kepada kamu sekalian, tatkala utusan kamu itu datang kemari maka ia masuk kemari bertemu dengan kami kepada suatu hari bulan Desember tahun seribu tujuh ratus sembilan puluh:1790: Maka ia mengadukan kepada kami, mengatakan itu perkataan kontrak perjanjian di dalam perkara yang ke delapan itu tiada boleh ia dipegangnya dan tiada boleh diturut adanya.

Bagi VOC pasal ini penting untuk memastikan bahawa siapapun yang menjadi raja Buton, ia tetap berada di bawah pengaruh mereka, meskipun mereka memberikan alasan bahawa hal itu dilakukan demi menjaga kestabilan politik dalam negeri Buton. Masalahnya, menurut para pembesar Buton:

"[d]ari hal itu pekerjaan yang mengeluarkan raja dan memasukkan raja, jikalau dikehendaki segerah2 memberi tahu dahulu kepada Kompeni, terlalu amat berat itu kepada kami, tiada boleh diturut, sebab kerana adat Tanah Buton jikalau adah raja yang keluar atau mati ta['] dapat tiada ia segera2 mengambil gantinya raja itu." (3: $7-10)$.

Sedangkan untuk melaporkannya ke Makassar memerlukan masa yang lama lantaran kedudukannya yang jauh dari ibu negeri Kerajaan Buton, Baubau. Akan tetapi, di sebalik masalah tradisi dan soal teknis itu, sebahagian kalangan kaomu dan walaka (kaum bangsawan) di Buton menganggap kewajipan untuk menunggu "restu" Kompeni dalam setiap pemberhentian atau pengangkatan raja baru, dianggap merendahkan atau menghina maruah Buton. Tambahan pula pertabalan Sultan dilakukan dengan proses yang juga menyertakan kitab suci al-Quran (Berg, 1939, p. 472). Sebaliknya Kompeni menilai tindakan mengingkari kesepakatan itu dipandang sebagai sikap menentang oleh pihak Buton terhadap mereka. Keadaan inilah yang menimpa Sultan Azimuddin (La Masalumu). Baginda diangkat menjadi Sultan Buton para peralihan tahun 1787 dan 1788, menggantikan Sultan Kaimudin yang mengundurkan diri kerana sudah tua dan sakit-sakit. Sultan Kaimudin memberitahu Kompeni di Makassar tentang calon penggantinya itu. Sultan Azimuddin sendiri telah menulis surat kepada Kompeni, yang balasannya ialah EAP212/6/3 yang dibicarakan dalam makalah ini. Akan tetapi, Kompeni tetap tidak menyukai Sultan Azimuddin, mungkin kerana baginda tidak bersetuju dengan isi Pasal 8 kontrak Perjanjian 1766. 
Dua pasal yang lainnya dalam kontrak perjanjian itu yang juga membuat pihak Buton berasa keberatan ialah Pasal 7 dan Pasal 9. Seperti telah disebutkan sebelum ini, Kompeni memberikan alasan bahawa Pasal 7, 8, dan 9 - dimaksudkan untuk menjaga kestabilan politik di Istana Wolio: supaya setiap proses pertabalan atau penggantian raja Buton tidak menimbulkan konflik politik dan supaya (9: $7-9)$ :

.. tiadalah kelak Sultan yang boleh tetap iqrar di atas tahta kerajaannya, meski ia baik perintahnya, meski baik fi'ilnya, kerana barang siapa kelak yang kuat iyalah mengaru biru kerajaan itu sehingga ia menjadikan dirinya raja.

Akan tetapi, Sultan Azimuddin, seperti beberapa pendahulunya, menganggap pasal tersebut sangat merugikan dan merendahkan martabat Buton. ${ }^{16}$

Inti ketiga pasal tersebut ialah: jika raja mangkat [kedatangan hakim Allah taala atau pulang ke rahmat Allah taala], maka para pembesar kerajaan harus bermesyuarat, kemudian wakil mereka harus segera menghadap Kompeni di Betawi, atau setidaknya di Ujung Pandang (Makassar) untuk disampaikan laporan mengenai keputusan mesyuarat itu (Pasal 7); para menteri dan pembesar Buton tiada sekali-kali dapat memutuskan sendiri calon pengganti raja yang mangkat atau mundur, tetapi harus melalui ketok palu (persetujuan) Kompeni (Pasal 8); dan apabila pihak Buton berani mengubah secara sepihak butir-butir perjanjian yang sudah dipersumpahkan itu dan berani "menyesatkan dirinya akan berseteru dengan Kumpeni", maka Kompeni akan "berbuat sekehendaknya hatinya" (menghukum Buton secara militer), yang akan menimbulkan "kebinasaan [pada] tanah negeri Buton nanti" (Pasal 9). ${ }^{17}$ Sejarah menunjukkan bahawa pasal ancaman ini tidak menakutkan beberapa orang sultan Buton, meskipun membuatkan beberapa bangsawan Kerajaan Buton yang lain gentar.

Yang berikut ialah penjelasan tentang konteks sejarah butir 2, iaitu tentang penjarahan kapal VOC Rustenwerk di Teluk Buton pada tahun 1752. Kisah ini penting untuk dijelaskan kerana kesannya sangat signifikan terhadap hubungan VOC dengan Buton sehingga beberapa dekad kemudian, seperti tercatat dalam warkah yang dibahaskan ini. Sebuah buku klasik karangan Bernadus Mourik memuatkan secara terperinci tentang kejadian yang berlaku terhadap kapal itu ketika berlabuh di Teluk Buton (pantai Kamali sekarang) pada 28 Jun 1752 petang. Buku karangan Mourik itu bertajuk: 
Twee-Rampspoedige Zee-reyzen, den eenen gedaan door ...Capitein Morin, met een Fransch Oost-Indisch Compagnie-schip, genaam Le Prince, behelzende een verhaal...op woensdag den 26 April 1752; den anderen met hel Hollandsch Oost-Indische Compagnie schip, genaam Rustenwerk, zynde ten anker leggende, in de Straat en voor het eiland Boeton, door de Mooren en Bokkaneezen, inwoonderen van dat eiland...jammerlyk vermoord geworden enz,; op woensdag den 28 juny 1752 yang diterbitkan di Amsterdam sekitar 1752 (lihat juga Mourik 1750: Lampiran [327]).

Buku itu menceritakan nahas dua kapal dagang Eropah. Kisah pertama (pp. 1 - 14) mengenai kapal Le Prince milik Perusahaan Dagang Perancis (Fransch Oost-Indisch Compagnie), dengan nakhoda "Capitein Morin", yang mendapat kemalangan akibat melanggar batu karang Turk dekat Pulau St. Michiel, kerana dilanda badai. Kapal itu kemudiannya terbakar. Peristiwa itu terjadi pada 26 April 1752 dalam pelayaran Le Prince menuju Podichery di India. Kejadian kedua - yang relevan dibicarakan di sini - ialah tentang kapal Rustenwerk milik VOC yang diserang di Buton pada 28 Jun 1752. Ketika itu Buton diperintah oleh Sultan Himayatuddin (La Karambau). Kisah nahas kapal Rustenwerk terdapat pada halaman 16 hingga 34 buku ini, dengan tajuk "Zee-reyze, Met verhaal nevens het AFLOOPEN van 't HOLLANDSCHE OOST-INDISCHE COMPAGNIE-SCHIP RUSTENWERK, voor 't EILAND BOETON, door de BOKKANEEZEN, in den jaare 1752" (Perjalanan laut, dengan sebuah cerita tentang diserangnya kapal VOC Rustenwerk di lepas pantai pulau Buton, oleh orang-orang Bugis pada tahun 1752; Gambar 3).

Rustenwerk berangkat dari Belanda ke Batavia pada 30 September 1749 di bawah nakhoda Kapten Mazius Tetting. Malangnya, nasibnya berakhir dengan tragedi di perairan Buton tiga tahun kemudian. Kisahnya secara ringkas: Rustenwerk, dalam perjalanan dari Maluku dan singgah di Buton. Pada hari Khamis, 22 Jun, kapal itu mendekati Baubau, ibu kota Kerajaan Buton. Rustenwerk singgah di situ untuk menambah perbekalan dan air minum, kemudian hendak meneruskan perjalanan. Namun begitu, pada Jumaat 23 Jun Kapten berhubung dengan seseorang pembantu penting dan orang kepercayaan Raja Buton. Bernardus Mourik (c.1752, pp. 20 - 21) menulis (terjemahannya):

Setelah mengisi Waterleggers kami, kami mengira sudah waktunya untuk berangkat, namun kapten kami telah menemui seseorang "preman" Makasar yang bernama FRANS FRANSZ., yang cekap 
berkomunikasi; dia telah mengunjungi BATAVIA, AMBON, TERNATE dan tempat lainnya, yang [juga] menjadi tempat tinggal Frans Fransz. dalam kehidupan sehari-harinya; bahkan, dia dulu tinggal serumah dengan syahbandar, yang di pulau itu menjadi orang ketiga di samping raja, dan juga berwibawa seperti rajanya untuk berdagang dengan orang Eropah; dia [ditugaskan] menghantar kepada majikannya laporan harian tentang interaksi dengan kami. Walaupun peristiwa ini memakan waktu beberapa hari, kami kadang-kadang berkesempatan untuk mendarat dan melihat dan meneliti pulaunya, dan juga penghuninya, tanamannya, atraksinya, dll.

Mengutip laporan Maksser Bijlagen Resolutie 1755 - 1756, Susanto (2010, p. 212) mengatakan bahawa Frans Fransz ialah seorang Bugis mantan jurubahasa di Bulukumba yang pernah menjadi "residivis" (orang yang pernah dihukum) dan dipenjara VOC di Makassar, setelah melakukan suatu rompakan pada 1750 . Ia dan anak buahnya dapat melarikan diri ke Pulau Kabaena yang termasuk wilayah kekuasaan Kerajaan Buton, dan tampaknya dilindungi oleh Sultan Himayatuddin. Tindakan Sultan Himayatuddin itu dinilai oleh VOC bertentangan dengan semangat Kontrak 1613 dan 1667. Frans Fransz sudah berada di Baubau ketika Rustenwerk singgah di lepas pantai ibu negeri Kerajaan di Buton itu pada akhir Jun 1752. Menurut Mourik (2010, p. 21) (terjemahannya):

Penyu, yang besar dan banyak, sangat bermanfaat bagi pulau ini, dan juga bagi matros kami, terutamanya pada waktu malam hari, (yang menjadi waktu yang paling pas); mereka kerap kali suka menangkapnya, mengangkatnya ke dalam perahu, dan memasaknya menjadi hidangan yang sedap; ketika kami mendarat, kami melihat banyak hal, setelah satu jam di jalan, kami sempat bertanya tentang sejumlah bangunan yang tinggi-tinggi: ini tempat apa? Jawapannya, ini adalah KALLASUSING. Penduduk asli yang berkulit hitam berbahasa Melayu, yang dicampur dengan beberapa bahasa lain, yang dipelajarinya dari bangsa-bangsa liar dan galak, seperti orang Bugis, dll., yang akan dibahas setelah ini. Raja pulau ini berbadan bagus, tetapi agak kecil tubuhnya ${ }^{18}$ seperti kebanyakan penduduknya, tetapi kakinya bagus dan lincah; sopan dan halus adat dan pakaiannya; sangat beradab terhadap orang luar, tetapi kalau memperhatikan pujian yang [sering] mereka ucapkan, seseorang pasti akan bosan; seperti kebanyakan penduduk pulaunya, mereka sangat mementingkan hasil curian, dan bersedia membunuh orang Eropah untuk mencapainya. 
Jadi, tampaknya kontak pertama antara kedua-dua belah pihak berlangsung lancar. Rustenwerk menunda masa untuk melanjutkan pelayarannya. Audiensi dilanjutkan pada keesokan harinya di kapal (Sabtu, 24 Jun). Sultan diwakili oleh Fans Fransz. Agenda pembicaraan utama antara kedua-dua belah pihak ialah masalah perdagangan. Pertemuan itu diakhiri dengan santap bersama. Hadirin bersulangan untuk kesihatan Sultan dan meriam dan Rustenwerk melakukan tembakan salvo sebanyak tujuh kali sebagai tanda hormat, tetapi kesepakatan antara kedua-dua belah pihak masih belum dicapai. Rombongan Frans Fransz kembali ke darat dan dilepaskan oleh Rustenwerk dengan lima kali tembakan salvo lagi.

Pada hari Ahad, 25 Jun, rundingan dilanjutkan lagi dan diteruskan dengan santap bersama. Beberapa jenis barang dijual oleh penduduk kepada anak-anak buah kapal. Suasana persahabatan tetap tampak antara kedua-dua belah pihak. Tiga hari berikutnya suasana penuh persahabatan itu masih berlanjutan, sehinggalah muncul sesuatu yang agak aneh pada hari Rabu, 28 Jun. Sekitar pukul 3 petang, Rustenwerk yang masih berlabuh di teluk Buton didekati oleh tujuh buah perahu, yang muncul dari muara Sungai Buton, yang membawa orang-orang Buton dan Bugis. Perunding Frans Fransz - si Mascafarfe Vryman (preman ${ }^{19}$ Makassar) - ada di salah satu perahu tersebut. Jumlah seluruh orang di atas perahu-perahu itu sekitar 450 orang. Anak buah kapal Rustenwerk Andries Wylander berasa curiga, tetapi tidak begitu diambil perhatian oleh kapten dan awak kapal yang lain.

Namun begitu, seperti hari-hari sebelumnya, Frans Fransz dan sebahagian pengiringnya masih diundang naik ke kapal dan bertemu dengan kapten kapal. Ada pembatasan jumlah tetamu yang diizinkan naik ke kapal. Sebahagian lainnya terpaksa tetap tinggal di perahu yang kelihatan sudah mengepung Rustenwerk. Pertemuan antara Frans Fransz dan awak pihak autoriti Rustenwerk berlangsung selama 2 jam, diselangi lagi dengan minum-minum (juga minum wain) dan saling bertukar rokok. Namun begitu, kesefahaman mengenai kontrak dagang masih belum dicapai oleh kedua-dua belah pihak. Tiba-tiba, pada pukul 5 petang terjadi kacau bilau di atas kapal. Salah faham telah berlaku antara Frans Fransz dan kapten kapal, yang mungkin disebabkan pengaruh alkohol, Frans Fransz dan anak buahnya mengamuk di atas kapal itu. Akhirnya, kedua-dua belah pihak saling menyerang dan membunuh dengan menggunakan pistol dan senjata tajam. Mourik (c.1752, p. 25) menulis (terjemahannya): 
Sementara itu, Frans Fransz menusuk kapten kami dengan tiga bacokan, lalu menjatuhkannya dari Halverdek - secara kasar dan penuh darah - ke atas badan salah seorang pegawai kami yang lain; dia mengira bahawa [temannya] sedang menuju ke atas untuk membantunya dengan membawa pedang; sementara itu orang Bugis yang kejam, dll., telah memasuki kapal kami dengan berteriak-teriak secara mengerikan, Amoka! Amoka! Drayan! Drayan!, lalu mereka, sebagai inkarnasi setan, menyerang dan membunuh semua orang yang berada di tempat itu dengan pedang dan pistol; sepengetahuan saya, mereka - iaitu para bangsat bedebah yang keji itu - yang masuk kapal kami pada saat yang berbahaya itu, berjumlah sekitar 300 orang.

Keadaan di kapal Rustenwerk menjadi kacau bilau. Anak buah Frans Fransz makin banyak naik ke kapal (lihat Rajah 5). Banyak orang luka-luka dan sebahagiannya jatuh ke laut. Banyak pula yang terbunuh dalam peristiwa itu dan para pengikut Frans Fransz menjarah isi kapal itu. Anak-anak kapal yang masih hidup juga ditahan sebelum dilepaskan. ${ }^{20}$

Akibat peristiwa penyerangan terhadap kapal Rustenwerk itu, hubungan Buton dengan VOC menjadi tegang. Kompeni benar-benar marah kepada "sekutu abadi"nya itu. Dengan dua kapal, Kaaskooper dan Carolina, VOC mengirim pasukan penghukum ke Buton di bawah komando onderkoopman Johan Banelius dan Kapten Melayu di Makassar, Abdul Kadir. Pasukan bantuan dari Ternate dan Bima juga dihantar dalam misi penghukuman itu. Tujuannya: menangkap si "preman Makassar" Frans Fransz dan anak buahnya. Terjadi pertempuran sengit di Kabaena, markas tempat pelarian Frans Fransz. Kapten Melayu Abdul Kadir berhasil menewaskan Frans Fransz, tetapi VOC harus membayar mahal kerana Johan Banelius terbunuh dalam pertempuran itu (Susanto, 2010, p. 212).

Lama kemudian VOC tidak juga mendapat penjelasan daripada Buton tentang motif di sebalik penyerangan terhadap kapal Rustenwerk itu. Markas VOC di Makassar lalu mengutus Johan Casper Rijsweber ke Baubau untuk memberikan peringatan. Jika utusan Sultan tidak segera datang ke Makassar, Buton akan dijatuhi hukuman yang lebih berat lagi melalui serangan ketenteraan yang lebih besar. Sultan Himayatuddin ( $\mathrm{Ca}$ Karambau) tidak menghiraukan ancaman VOC tersebut. Namun begitu, kalangan bangsawan Buton ( kaomu dan walaka) cukup panik. Mereka tidak ingin terjadi pertumpahan darah yang tentu akan merugikan Buton. Sultan Himayatuddin diminta untuk turun takhta. Baginda mencintai rakyatnya dan sanggup bersetuju dengan permintaan kaomu dan walaka. Beliau digantikan 


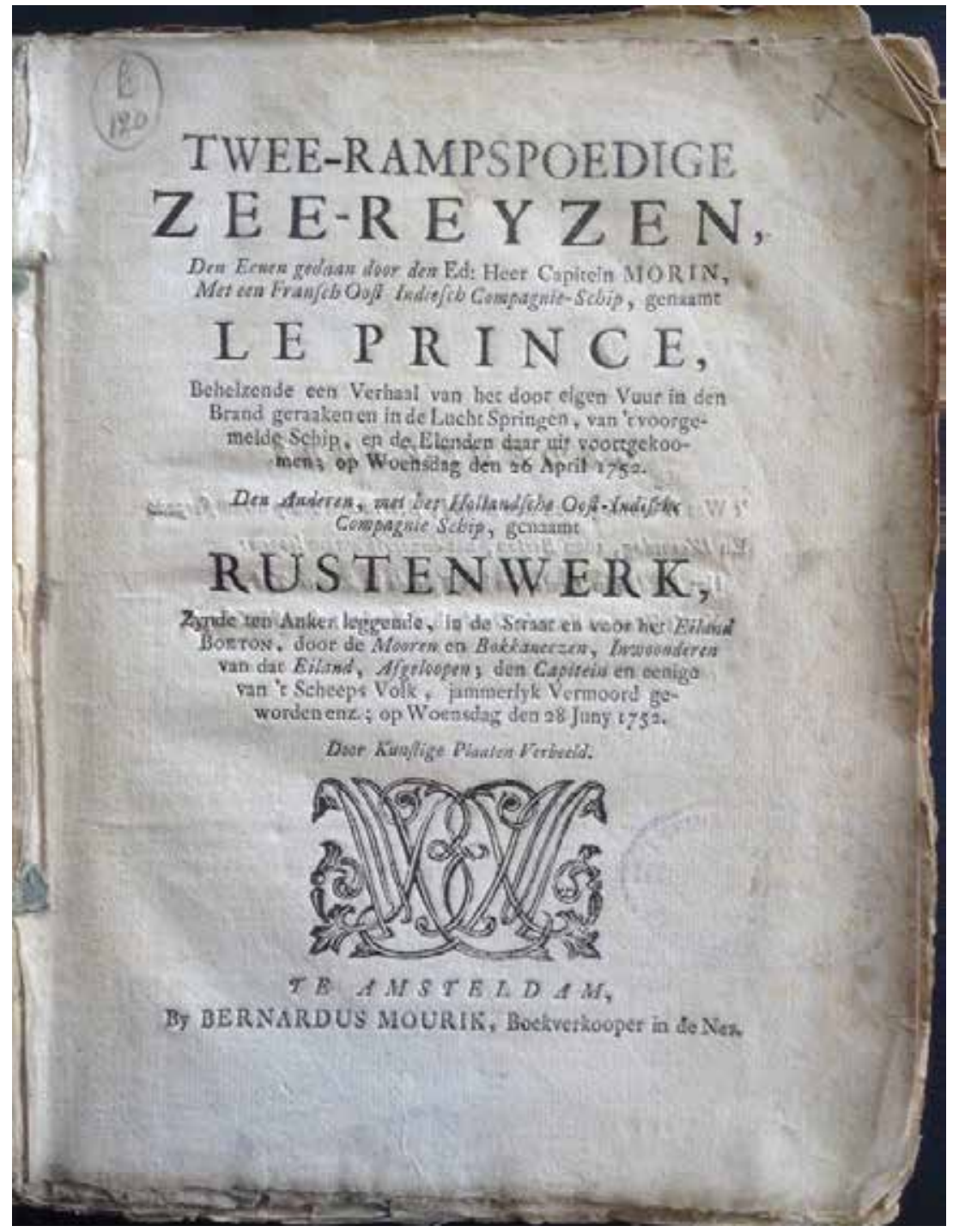

Rajah 4 Sampul dalam buku Bernardus Mourik (c.1752] yang menceritakan kisah kemalangan kapal French Oost-Indische Compagnie Le Prince yang melanggar batu karang Turk di dekat Pulau St. Michiel pada hari Rabu, 26 April 1752 (pp. 1-14) dan kapal Hollandsche Oost-Indische Compagnie (VOC) Rustenwerk yang dijarah oleh orang-orang Mooren dan Bokkanezen (orang-orang liar dan orang Bugis) di bawah pimpinan Frans Fransz di teluk Buton pada hari Rabu, 28 Jun 1752 (pp. 16-37) (Courtesy Universiteitsbiblotheek Leiden). 


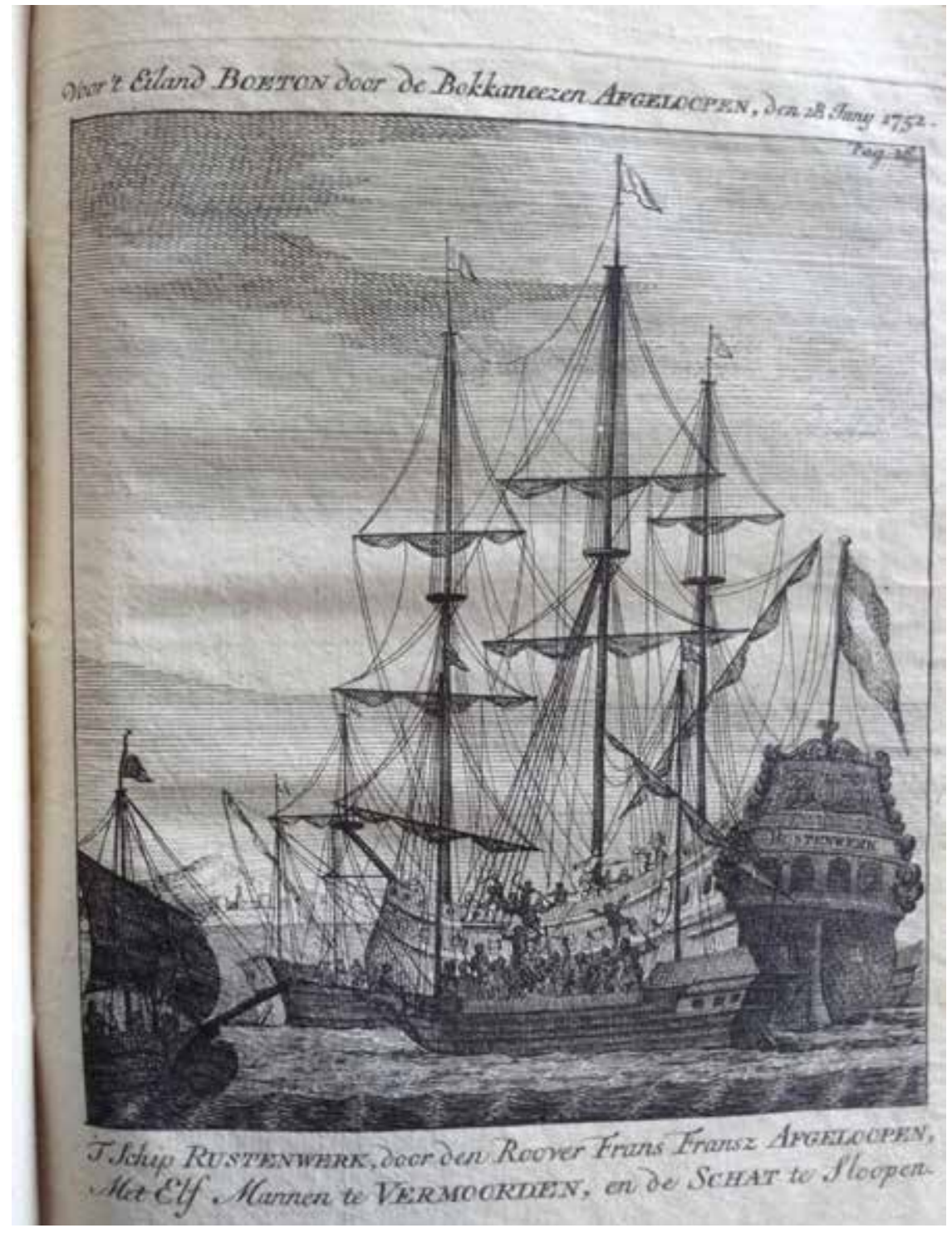

Rajah 5 Ilustrasi yang menggambarkan penyerangan kapal Rustenwerk yang sedang berlabuh di teluk Buton oleh Macaffaren Vryman ("preman Makassar") Fans Fransz dan pengikutnya pada hari Rabu, 28 Jun 1752 (Sumber: Mourik, c. 1752, p. 26 (Ihsan Universiteitsbiblotheek Leiden). 
oleh Sultan Sakiuddin. ${ }^{21}$ Penggantian sultan itu tidak membuat hubungan Buton dengan VOC segera menjadi baik. VOC menduga La Karambau tetap berkuasa dan pengaruhnya tetap besar dalam lingkungan Istana Wolio (Susanto, 2010, pp. 213 - 227).

VOC mengemukakan dua perjanjian kepada Sultan Sakiuddin: pengukuhan kembali Perjanjian 1667 dan ganti rugi terhadap kerugian yang dialami Rustenwerk dengan budak. VOC meminta $1000^{22}$ orang budak. Sultan tidak sepenuhnya memenuhi permintaan VOC itu. Sebanyak 80 orang budak, kebanyakan sudah tua, dihantar ke Makassar menyertai kunjungan utusan Buton ke markas VOC itu pada 25 Disember 1754. Sebelumnya, sudah dikirim 72 orang budak berserta sejumlah emas dan perak. Dalam pada itu, telah berlangsung tiga kali surat-menyurat antara Baubau dan Makassar untuk mengurangi ketegangan selepas penyerangan terhadap kapal Rustenwerk itu.

Akan tetapi VOC tidak juga berpuas hati. Buton dianggap tidak bersungguh-sungguh, dan hukuman ketenteraan akan dilakukan. Pada 19 Februari 1755, kapal-kapal VOC yang diketuai J.C. Rijsweber menyerang Baubau. Peperangan terjadi antara kedua-dua belah pihak. Banyak rakyat Buton terbunuh dan yang masih hidup banyak yang berpindah untuk menyelamatkan diri. Beberapa orang bangsawan Buton juga terkorban. Kerugian wang dan nyawa manusia besar sekali. ${ }^{23}$ Peristiwa yang memilukan hati dan, akibatnya, terpendam jauh dalam memori kolektif orang Buton. Susanto (2010; juga Susanto, 2015) menggambarkan tempoh peperangan ini secara terperinci dengan mengutip sumber tempatan, khususnya naskhah Kabanti Ajonga Inda Malusa (Pakaian yang tidak luntur') yang ditulis oleh H. Abdul Ganiu yang hidup pada masa pemerintahan Sultan Buton ke-29, La Ode Muhammad Idrus Kaimuddin. ${ }^{24}$ Serangan VOC itu kemudian dihentikan kerana ada isyarat kompromi dari Istana Wolio.

Pada 8 Ogos 1756, Rijsweber dan Sinkelaar datang lagi ke Buton. Mereka masih menuntut 1000 orang budak sebagai ganti rugi atas penyerangan kapal Rustenwerk oleh Frans Fransz dan anak buahnya. Sultan Sakiuddin meminta diberikan sedikit waktu dan keringanan.

Seterusnya pengesahan Kontrak Perjanjian 1766, setelah 10 tahun penyerangan VOC terhadap Baubau. Ketika itu Buton dipimpin oleh Sultan Kaimuddin atau La Jampi. Jelas nada kontrak itu adalah untuk "meneguhi" dan "menguatkan akan persaudaraan kita [Kompeni-Buton] seperti yang telah sudah ada itu" 25 yang "rosak" kerana kes Rustenwerk. Persumpahan kontrak itu disaksikan pula oleh Raja Bone. Dalam pengantar kontrak itu, 
VOC masih menyinggung "kesalahan" yang sudah dilakukan Sultan Buton sebelum ini (La Karambau) yang "memberi malu kepadanya dan lagi ditaruhnya di bawah tapak kaki akan perjanjian kami [VOC] yang sudah diperbuat dengan segala raja-raja yang dahulu-dahulu ditaruhnya oleh raja yang sudah mengangkat sampai atas Qur'an bukannya sebab kekurangan Kumpeni." (Kontrak 1766 dalam Susanto, 2010, pp. 315 - 16). Kontrak itu masih juga menyebut-nyebut "orang yang lima ratus", yang merupakan jumlah budak yang masih berbaki yang harus dibekalkan oleh Buton kepada Kompeni sebagai ganti rugi atas kerosakan kapal Rustenwerk. Jika merujuk butir 3 isi warkah, seperti disebutkan di muka, maka bererti bahawa sehingga 1791 hutang 1000 orang budak yang diminta VOC sebagai ganti rugi atas kejadian serangan terhadap kapal Rustenwerk yang terjadi tahun 1752 belum juga lunas.

Butir 4 isi warkah - soal meriam dan barang milik Kompeni yang ada di Baubau, sama ada dipinjamkan ataupun diambil daripada kapal VOC yang mengalami kecelakaan - tampaknya juga menjadi ganjalan serius dalam hubungan VOC dengan Buton. Dalam konteks ini jelas sekali sifat Belanda: untung boleh, tapi rugi tidak mahu. Menurut Pasal 12 Kontrak Perjanjian 1766, Raja Buton harus menolong sebarang kapal Kompeni yang lalu, singgah untuk menambah perbekalan, atau tersangkut [mengalami kemalangan] di Buton (Kontrak 1766 dalam Susanto, 2010, p. 324). Kapal Kompeni yang pecah di perairan Buton, yang isinya diambil oleh orangorangnya Sultan Buton, yang disebut dalam warkah ini masih belum dapat dikenal pasti. Tampaknya, peristiwa kecelakaan kici itu mungkin belum lama terjadi (mungkin akhir 1780-an), sebab dikatakan: "kici yang baharu2 ini pecah adanya" (6:13; kursif oleh Suryadi).

Butir 5 isi warkah jelas berkaitan dengan kawalan VOC terhadap laut dalam usaha mempertahankan dominasinya untuk menguasai perdagangan rempah di Nusantara. Akses perahu-perahu Buton untuk melayari pelbagai tempat di bahagian timur Kepulauan Nusantara dikawal oleh VOC dengan keperluan untuk memiliki "surat pas". Kewajipan untuk mempunyai "surat pas" ini dilaksanakan setelah VOC setelah memperoleh kemenangan atas Gowa pada 1669 yang kemudian memberikannya ruang seluas-luasnya untuk menguasai dan mengawasi perdagangan rempah di Kepulauan Maluku dan sekitarnya. Seperti dikatakan Nolde $(2015$, p. 6):

Gowa's defeat also resulted permanent Dutch presence in South Sulawesi and the creation of a system of port-control, maritime 
patrols, and sailing passes designed to regulate and restrain the movement of people and goods between Makassar and other areas of the Indo-Malay archipelago.

Butir 6 isi warkah berkait erat dengan Pasal 1 Kontrak 1766, iaitu keharusan bagi Buton untuk "membunuh" (memusnahkan) pohon-pohon pala dan cengkeh di "atas sekalian pulau-pulau Tukang Besi yang takluk di bawahnya [Buton] itu dan lagi demikian [Pulau] Ka[1]edupa dan Wanci", dan juga di Pulau Binongko. Sebagai pampasan, VOC membayar 100 riyal per tahun kepada Sultan Buton. Tapi riyal hanya "akan dibayar[kan] jikalau Kompeni sudah membunuh pohon-pohon sekalian itu." (Kontrak 1766 dalam Susanto, 2010, p. 317). Isu pemusnahan pohon-pohon cengkeh dan pala ini masih muncul dalam warkah ini, yang nota bene sudah berjarak 35 tahun sejak Kontrak 1766 dipersumpahkan. Seperti dinyatakan oleh Susanto (2010, pp. 242 -248), proses pemusnahan pohon rempah ratus itu tidak mudah: banyak kendala ditemui di lapangan, antara lain, wilayah tempat tanaman pohon pala dan cengkeh itu sangat jauh dan sukar dijangkau. Selain itu, penduduk setempat menghalang orang-orang yang ditugaskan oleh VOC untuk melaksanakan tugas itu.

Butir 7 lebih merupakan pengulangan nada ancaman yang sudah disebutkan dalam Pasal 9 Kontrak 1766. Jika diamati lebih jauh, semacam gaya Belanda tulen (yang masih dipraktikkan sehingga sekarang) dalam berhubung dengan rakyat dari negeri-negeri yang mereka anggap lemah dan lebih rendah daripada mereka. Zaman Hakeruna Walanda (1755) jelas salah satu pewujudan daripada ancaman ini. Pihak VOC menyebutnya sebagai "hukuman" terhadap Buton kerana melanggar kontrak perjanjian yang sudah dipersumpahkan. Sebelum perang 1755, sudah beberapa kali Buton diserang oleh "sekutu abadi"nya itu (Susanto, 2010, pp. 200 - 203). Intinya: jika VOC berasa rugi, Buton akan menerima ganjarannya dalam bentuk serangan ketenteraan.

\section{SULTAN AZIMUDDIN}

Abdul Mulku Zahari dalam tiga jilid bukunya yang menyenaraikan rajaraja yang pernah memerintah Kerajaan Buton (Abdul Mulku, 1977, Vol. I, II, III) tidak menyebut nama Sultan Azimuddin. Pada akhir Jilid II (pp. 148 - 156) ia menjelaskan Sultan Alimuddin (La Masalumu), Sultan Buton ke-25, yang memerintah antara 1788-1791. Selanjutnya, dalam Jilid III, halaman 13 hingga 20, menjelaskan Sultan Buton ke-29, Muhuyuddien 
Abdul Gafur. ${ }^{26}$ Merujuk warkah ini, dikatakan bahawa Sultan Azimuddin mengirim warkah rasmi kepada VOC di Makassar pada 1 November 1790 (1:13), bererti bahawa beliaulah yang menjadi Sultan Buton yang sah pada waktu itu. Sedangkan Abdul Mulku Zahari (1977, II, p. 148) - yang juga dirujuk oleh Susanto (2010, p. 334) - mengatakan pada tahun itu yang memerintah Buton ialah Sultan Alimuddin. Hal ini sedikit membingungkan: apakah Sultan Alimuddin dan Sultan Azimuddin orang yang sama? Akan tetapi, huraian Susanto menunjukkan bahawa Sultan Azimuddin dan Sultan Alimuddin ialah raja yang sama.'

Pada peralihan tahun 1787 dan 1788, karena sudah tua dan alasan sakit, Sultan Kaimuddin mengundurkan diri dari jabatannya. Sebagai penggantinya ditunjuk La Masalumu bergelar Sultan Azimuddin. Sesuai dengan bunyi Pasal 8 [Kontrak Perjanjian 1766], [Sultan] Kaimuddin memberitahukan [pengunduran dirinya, tapi belum menyebut dengan jelas calon penggantinya] kepada Kompeni di Makassar (Susanto, 2010, pp. 251 - 252).

Huraian Ab. Razak et al. (2011, pp. 29,32) juga menunjukkan bahawa Sultan Alimuddin dan Sultan Azimuddin ialah orang yang sama. Yang pasti, Sultan Azimuddin (Alimuddin) tidak disukai Kompeni Belanda. EAP212/6/3 mengatakan bahawa "[n]iscaya Tuan Jeneral dan segala Rat van India di Betawi tiada ia mau menjadikan raja di Buton itu Sultan Azimuddin, akan tetapi ia berkirim surat kemari di Mengkasar, ..." (10:3 - 4). Penyataan ini menunjukkan bahawa VOC tidak mahu Azimuddin menjadi raja Buton, walaupun setelah ditabalkan sebagai Sultan Buton ia segera mengirim warkah pemberitahuan ke Makassar. Warkah pemberitahuan itu agak terlambat dikirimkan ke Makassar, kerana dalam bulan Februari 1791, VOC dan para bangsawan di Istana Wolio yang menjadi sekutunya sudah "berembuk" (berunding), yang akhirnya melahirkan Kontrak Perjanjian 1791.

Alasan penolakan VOC terhadap Sultan Azimuddin lebih kerana baginda, seperti halnya pendahulunya La Karambau, cukup tegas, punya harga diri, dan tidak mahu tunduk begitu saja kepada pasal-pasal kontrak perjanjian yang sudah dipersumpahkan (ditandatangani) oleh para pendahulunya, khususnya Kontrak Perjanjian 1766. Susanto (2010, p. 253), yang mengutip redaksi Kontrak Perjanjian 1791 (tidak lama kemudian Sultan Azimuddin disingkirkan), menunjukkan bahawa "raja yang baru di Buton itu yang bernama Sultan Azimud[d]in...dan sekalian wazir menteri-menterinya... tiada melakukan sentiasa perkataan sebagai yang telah tersebut di dalam [kontrak] perdamaian yang telah dibuat dahulu-dahulu itu adanya." 
Menurut Susanto, telah terjadi perpecahan dalam kalangan bangsawan Buton setelah Sultan Kaimuddin meletakkan jawatan sebagai raja Buton, yang berpotensi membahayakan keutuhan kerajaan. Pertelingkahan dalam kalangan elit Buton itu tampaknya lebih berkait dengan adanya perbezaan pandangan dalam sikap terhadap kontrak-kontrak perjanjian dengan VOC, sesuatu yang sebenarnya sudah berulang kali terjadi dalam lingkungan bangsawan Buton. Keadaan yang cukup genting itu "mendorong VOC lebih kuat untuk mencampuri urusan penggantian Sultan Buton. Ketika Kontrak Perjanjian 19 Februari 1791 dibicarakan dan kemudian disepakati, kejatuhan Sultan Azimud[d]in yang tidak direstui VOC [itu] tinggal menunggu hari saja" (Susanto, 2010, p. 252). Sejarah telah mencatatkan bahawa pada akhir tahun itu juga (sangat mungkin setelah November 1791, sebab warkah yang dibahaskan ini, yang dikirim pada bulan ini, masih ditujukan kepada Sultan Azimuddin) sang Sultan (di)turun(kan) dari takhtanya, digantikan Sultan Muhuyuddien Abdul Gafur yang, berdasarkan analisis terhadap warkah rasmi yang dikirimkannya kepada VOC (Suryadi, 2007a), ialah seorang raja yang sangat "penurut" dan patuh kepada Kompeni.

\section{KESIMPULAN}

Warkah Kompeni kepada Sultan Azimuddin yang dipaparkan dalam makalah ini, memberikan beberapa refleksi kepada kita tentang situasi Kerajaan Buton pada akhir kurun ke-18. Pertama, cukup jelas bahawa kes penjarahan kapal Rustenwerk yang terjadi dalam bulan Jun 1752 memberikan kesan yang panjang dan cukup buruk kepada hubungan Buton dengan VOC. Akibat perisiwa itu, Buton diserang oleh VOC secara besar-besaran pada 1755, yang menimbulkan kepiluan pada pihak Buton kerana beberapa petinggi kerajaan daripada kaum bangsawan (kaomu dan walaka) dan banyak rakyat yang tidak berdosa mati dalam pertempuran. Hampir empat dekad setelah peristiwa nahas itu, kasus Rustenwerk masih tetap menjadi pokok masalah dalam hubungan Buton dengan VOC. Tidak pernah selesai masalah itu kerana Buton sukar memenuhi pembayaran ganti rugi sebanyak 1000 orang budak seperti yang diminta VOC.

Kedua, dengan membandingkan pasal-pasal beberapa kontrak perjanjian antara Buton dengan VOC, dapat dikesan bahawa Belanda terus berusaha mempersempit ruang gerak autoriti Buton. Pasal-pasal tambahan atau yang diubah lebih cenderung menguntungkan Belanda dan merugikan Buton. Hal ini mengingatkan kita pada pepatah Melayu "Seperti Belanda minta tanah" atau "Diberi hati minta jantung". Belanda terus mendesak Buton terhadap 
keinginannya. Dalam konteks ini, dapat difahami mengapa beberapa orang raja Buton yang berasa kecewa dan marah, kerana mereka masih punya harga diri dan martabat, tidak mahu tunduk begitu saja pada kontrak-kontrak perjanjian dengan Kompeni itu. Sultan Azimuddin antara salah seorang raja yang menentangnya, di samping La Karambau (Sultan Himayatuddin), yang sangat teguh menjunjung harga diri orang Buton. Peristiwa Rustenwerk terjadi di hujung pemerintahannya yang pertama.

Ketiga, sampai batas tertentu ada kesan bahawa persepsi terhadap kontrak-kontrak perjanjian tertulis berbeza antara orang Eropah (dalam hal ini Belanda) dan orang bumiputera (dalam hal ini para bangsawan dan raja-raja Buton). Lebih jauh lagi, ini mungkin menyangkut perbezaan kontras antara tradisi literasi (literacy) Barat yang sudah begitu kuat hidup dalam budaya Belanda di satu pihak dan kelisanan (orality) yang menjadi ciri umum etniketnik yang hidup di Kepulauan Nusantara di lain pihak. Redaksi EAP212/6/3 menyiratkan bahawa pihak Buton sering tidak mengendahkan kontrakkontrak tertulis yang sudah dibuat dengan Belanda. Hal ini memberikan kesan bahawa jika sebuah kontrak perjanjian dipersumpahkan oleh seorang raja, maka tidak ada keharusan mutlak bahawa raja-raja yang lain yang memerintah sesudahnya wajib mematuhinya. Memang harus diakui bahawa ada pula pihak-pihak di kalangan bangsawan Buton yang memegang teguh setiap perjanjian yang telah dibuat dengan Kompeni. Juga ada kesan bahawa rakyat Buton tidak berasa langsung terikat dengan pasal-pasal kontrak perjanjian tertulis yang dibuat oleh golongan elit mereka dengan VOC. Hal ini tergambar dalam kes sulitnya melaksanakan pemusnahan pohon-pohon cengkeh dan pala di Kepulauan Tukang Besi, yang mestinya dilakukan oleh Buton mengikut Pasal 1 Kontrak Perjanjian 1766, kerana rakyat acuh tak acuh saja dan malah banyak yang menghalang tindakan ini.

Sampai batas tertentu kontrak-kontrak perjanjian antara Buton dengan VOC mempengaruhi pola hubungan politik dalam kalangan kaum bangsawan Buton. Walau tiada garis batas yang tegas, dapat dikatakan bahawa kalangan kaomu dan walaka sering berbeza pendapat dalam hal kontrak perjanjian yang dibuat dengan VOC. Namun demikian, walau sering terjadi gejolak dalam lingkungan Istana Wolio akibat perbezaan perspektif dalam menunjukkan sikap terhadap kontrak-kontrak yang cenderung dikemudi oleh Kompeni itu, tapi hal itu tidak sampai menimbulkan perang saudara dan perbalahan serius dalam kalangan bangsawan Buton yang boleh mengancam keutuhan kerajaan. Sehubungan dengan hal ini, menarik hal yang disebut Susanto Zuhdi (2010, p. 221) sebagai perasaan menyalahkan diri sendiri yang 
dirasakan orang Buton apabila mendapat "hukuman" daripada VOC. Hal ini sedemikian apabila dihubungkan dengan sikap elit Buton yang menganggap diri mereka sebagai “anak" dan Kompeni sebagai "ayah", walaupun konsep itu, melalui warkah-warkah Sultan Muhyuddien Abdul Gafur kepada VOC (Suryadi 2007a), sering pula dimanfaatkan oleh Buton untuk mengakali (menipu) Kompeni, misalnya meminta tanggung jawab sang "ayah" untuk mengirimkan senapang, ubat bedil (mesiu), meriam, teropong, dan barang berharga lainnya untuk dikirimkan ke Istana Wolio. Logiknya: seorang "ayah" tentu harus memenuhi permintaan sang "anak", kalau ia memang mencintainya.

Akhirnya, harus dipertimbangkan Sultan Azimuddin (Alimuddin) yang masa kekuasaannya cukup pendek (kerana tekanan Belanda). Beliau seorang pemimpin Buton (La Karambau) yang tahu akan harga diri dan martabat rakyat Buton, dan tidak mahu begitu saja diatur kerajaannya oleh kekuatan asing (VOC). Untuk pemimpin seperti ini, orang Buton pada zaman ini tentu dapat memikirkan di manakah maruah beliau harus ditempatkan.

\section{PENGHARGAAN}

Makalah ini dibentangkan dalam diskusi anjuran Pusat Dokumentasi Melayu, Dewan Bahasa dan Pustaka (DBP), Kuala Lumpur, dengan tajuk Wacana Sarjana Persuratan Melayu, pada 18 Januari 2018. Rakaman terima kasih kepada Puan Kamariah Abu Samah, pengerusi diskusi dan kepada para peserta diskusi yang telah memberikan komen yang berharga untuk penyempurnaan makalah ini.

\section{NOTA}

1 Lihat: http://eap.bl.uk/database/results.a4d?projID=EAP212 (diakses 14 Jun 2017).

2 Lihat:http://eap.bl.uk/database/overview_item.a4d?catId=33475;r=24393 (diakses 15 Jun 2017).

3 Untuk kajian di bidang ini yang berkaitan Buton, lihat misalnya Shellabear (1898), Suryadi (2007a,b), Suryadi (2010), Suryadi (2015). Lihat juga Abdul Mulku Zahari (t.th).

4 Banyak ahli sejarah Barat, dan tak kurang pula ahli sejarah dari dalam negeri yang mengkaji sejarah kolonialisme di Indonesia, tidak boleh membaca huruf Jawi, suatu kelemahan dalam kurikulum ilmu sejarah yang sehingga kini belum disedari (lihat: https://newbooks.asia/review/exile-colonial-asia; diakses 2 Januari 2018). Dalam konteks Buton, karya Susanto Zuhdi (2010) ialah suatu pengecualian. Beliau telah menggunakan sumber primer tempatan yang amat kaya, termasuk warkah kerajaan 
Buton, untuk merekonstruksi sejarah masa lampau Buton.

5. Maksudnya: ditulis di Benteng Fort Rotterdam, Makassar, pada 25 Februari 1791. Benteng ini diperkuat oleh VOC setelah mereka memperoleh kemenangan atas Gowa yang dibantu oleh orang-orang Bugis dari Kerajaan Bone (Sutherland, 2011).

6 Kita dapat bercermin daripada model warkah-warkah kontrak antara VOC dengan raja-raja lokal dalam period ini, termasuk dengan Buton. Demikianlah umpamanya, dalam naskhah Kontrak Sultan Butun (Buton) dengan VOC, 27 Disember 1794 disebutkan: "[A]dapun kontrak perdamaian itu adalah suatu serupahnya di dalam tangan kerajaan Butun itu, inilah kami suruhkan bacakan kamu akan bernyata-nyata kamu daripada perkataan bahasa Wilandanya dan bahasa Melayunya diartikan baikbaik maknanya sekalian kepada utusan itulah.” (dipetik dari Susanto, 2010, p. 331).

7 Komuniti Melayu sudah lama bertapak di Makassar, misalnya salah seorang tokohnya yang terpenting, Datuk Maharaja Lela, yang mendapat tempat istimewa di kalangan penguasa Gowa dalam kurun 1660-an (Sutherland, 2001, p. 400).

8 Mengenai pemerintahan Buton di bawah Sultan Dayanu Ikhsanuddin, lihat Nurhayati (2003).

9 Lebih jauh mengenai posisi Buton dalam peta politik regional kepulauan Nusantara bagian timur pada masa VOC, lihat Ligvoet (1878) dan Kielstra (1908). Schoorl (1991), yang kemudian diterjemahkan ke dalam Bahasa Indonesia (Schoorl et al., 2003, Bab 2), dan Susanto Zuhdi (2010), merupakan dua rujukan semasa yang merangkumkan banyak sumber klasik mengenai Buton.

10 Kerajaan Ternate semakin lemah setelah kemangkatan Sultan Babullah (1570 1583). Dalam tahun 1606 pesaingnya, iaitu Kerajaan Tidore, bekerjasama dengan orang-orang Sepanyol, berjaya menduduki Ternate. Akibatnya, Ternate terpaksa meminta bantuan kepada VOC. Dalam tahun 1607 ditandatangani persekutuan antara Ternate dan Belanda (Fraassen, 1987, I, pp. 45 - 47) (Catatan Suryadi).

11 Pembelian budak dari Buton ini, akhirnya Batavia memiliki komuniti orangorang yang berasal dari Buton yang sudah terbentuk sejak pertengahan kurun ke17 (yang kemudian dikenal sebagai Kampung Buton). Tempat tinggal dan aktiviti mereka diatur oleh Belanda (lihat misalnya Instructie voor het Europesche hoofd van de Javanen, Balinezen en Boetonezen te Batavia Instructie voor het Europesche hoofd van de Javanen, Balinezen en Boetonezen te Batavia oleh Gabenor Jeneral J. Maetsyker [1653 - 1678], bertarikh 1 Disember 1665, dalam Chijs, 1886, pp. $406-$ 407). Selain budak yang dibeli, juga banyak budak yang dihadiahkan oleh raja-raja Buton kepada Gabenor Jeneral VOC, seperti yang terdapat dalam banyak kolofon warkah raja-raja Buton kepada Gabenor Jeneral VOC / Hindia Belanda di Batavia (Suryadi, 2007a, 2007b) (Catatan Suryadi).

12 Tanda ini merujuk halaman naskhah asli warkah yang dibahas, maksudnya: halaman 13, baris 11.

13 Penyelidik masih belum dapat mengenal pasti keberadaan warkah ini dan belum dapat diketahui isinya secara nyata dan lengkap. Akan tetapi dengan menganalisis isi warkah balasan Kompeni ini, tentu kita boleh mengambil kira isi warkah yang dikirimkan oleh Sultan Azimuddin kepada Gabenor VOC di Makassar itu.

14 Sultan Buton ke-24 (masa bertahta: 1763 - 1788), sila lihat Abdul Mulku (1977, II, pp. 139 - 47).

15 Perjanjian ini "dipersumpahkan" (disahkan) oleh kedua-dua belah pihak di atas 
kapal VOC Thertolen setelah dicapainya kesepakatan untuk menghentikan serangan VOC terhadap Buton yang dilakukan oleh Cornelis Speelman dan para sekutunya. Pengesahan kontrak perjanjian itu dihadiri pula oleh Sultan Ternate, Mandarsyah, "suatu petunjuk masih ada pengaruh Ternate di Buton, seperti terlihat dalam Pasal 7 [perjanjian itu]" (Susanto, 2010, p. 204).

16 Salah seorang sultan Buton yang tidak mahu tunduk begitu saja kepada isi kontrak perjanjian Buton dengan VOC yang dibuat oleh para pendahulunya ialah Sultan Himayatuddin ibnu Sultanaani Liyaauddin Ismail Muhammad Saydi atau La Karambau (bertahta 1751 - 1752 dan 1760 - 1763). Demikianlah umpamanya, La Karambau menilai "kontrak perjanjian Speelman[-]Simbata [itu] adalah suatu penghinaan terhadap kerajaan Buton [dan juga] menimbulkan kerugian yang mengakibatkan rakyat kerajaan Buton melarat" (Abdul Mulku, 1977, II, p. 116). Lebih jauh tentang La Karambau dan keadaan Buton pada masa pemerintahannya, lihat Abdul Mulku (1977, II, pp. 115 - 118) dan Susanto (2015).

17 Selengkapnya mengenai ketiga pasal itu, lihat Susanto Zuhdi (2010, pp. 321 - 322).

18 Maklumat ini agak bertentangan dengan maklumat daripada sumber tempatan yang mengatakan bahawa La Karambau (Sultan Himayatuddin) - jelas dialah raja yang dimaksudkan di sini - ialah sebuah nama kiasan yang diberikan orang Buton kepada raja mereka itu yang berperawakan tinggi besar seperti kerbau dan bersifat kesatria (Susanto, 2010, p. 211) (Catatan Suryadi).

19 Pada masa itu kata "vryman" bererti orang yang bebas, yang tidak mahu terikat kepada satu institusi/lembaga atau kekuatan. Makna "bebas" ini masih terus digunakan pada kata preman yang dikenal dalam Bahasa Indonesia sekarang, tetapi sudah berkonotasi negatif.

20 Diringkaskan daripada Mourik (c.1752).

21 Sultan Saki[y]uddin atau Sangia Wolowa bertahta dari tahun 1752 - 1759. Baginda berasal daripada kalangan bangsawan Kumbewaha yang ke-4. Lebih jauh tentang beliau, lihat Abdul Mulku (1977, II, pp. 119 - 32).

22 Susanto Zuhdi (2010, p. 214 [Catatan 19]) mengatakan bahawa dokumen tentang jumlah budak sebagai ganti rugi atas penyerangan kapal Rustenwerk ini tidak pernah ditemukan. Namun begitu, warkah Kompeni kepada Sultan Azimuddin yang kita bahas ini dengan jelas menyebutkannya: "[m]eminta seribu 1000: kepala budak pembayarnya kerugian Kompeni kepada kapal yang bernama Rustenwerk” (3: 20 21).

23 Maklumat lanjut tentang penyerangan VOC atas Buton ini dan kesan sosial politik dan kewangannya, sila lihat Susanto Zuhdi (2010, pp. 215 - 227) dan Susanto Zuhdi (2015).

30. Maklumat lanjut tentang teks ini, sila lihat La Niampe (1999) dan Ali (2015).

31. Petikan daripada teks Kontrak 1766 ini merujuk Susanto Zuhdi (2010, pp. 311 -328).

32. Tentang warkah-warkah Sultan Muhuyuddien [Muhyiuddin] Abdul Gafur, lihat Suryadi (2007a). 


\section{RUJUKAN}

Ab. Razak Ab. Karim, dkk. (2011). Masyarakat Melayu Buton: Kilauan khazanah manuskrip, kesenian, budaya, bahasa dan pantunnya. Kuala Lumpur: Akademi Pengajian Melayu, Universiti Malaya.

Abdul Mulku Zahari. (1977). Sejarah dan ada fiy Darul Butuni [Buton]. Jakarta:

Proyek Pengembangan Media Kebudayaan, Departemen Pendidikan dan Kebudayaan. [3 Jilid].

Abdul Mulku Zahari. (t.th.) (Penyalin \& Penerjemah). Surat-surat Perjanjian VOC - Kesultanan Buton. Baubau: Koleksi Keluarga Abdul Mulku Zahari.

Achadiati Ikram, Tjiptaningrum Fuad Hassan, dan Dewaki Kramadibrata. (2001).

Katalog naskah Buton koleksi Abdul Mulku Zahari. Jakarta: Masyarakat Pernaskahan Nusantara - Yayasan Obor Indonesia.

Ali Rosdin. (2015). Nilai-nilai kehidupan masyarakat Buton: Kajian filologi dan sosiologi sastra serta suntingan teks dan terjemahan terhadap naskah Kabanti Ajonga Yinda Malusa (Disertasi Universitas Gadjah Mada, Yogyakarta).

Berg, E. J. van den. (1939). Adatgebruiken in verband met de sultanistallatie in Boeton. Tijdscrift voor Indische Taal-, Land-en Vokenkunde 79, 469 - 528.

Chijs, J. A. Van der (Mr.). (1886). Nederlandsch-Indisch Plakaatboek, 1602 1811. Batavia: Landsdrukkerij; 's Hage: M. Nijhoff [Tweede Deel].

Cense, A.A. (1954). Mededelingen uit de verslagen van Dr E.J. van den Berg; Taalambtenaar op Buton 1936 - 1941. Bijdragen tot de Taal-, Land- en Volkenkunde 110(2), $154-184$.

Corpus Diplomaticum. (1907). Corpus Diplomaticum Neerlando-Indicum (ed.: J.

E. Heeres). 's-Gravenhage: Nijhoff [Jilid 1].

Fraassen, Ch. F. Van. (1987). Ternate, de Molukken en de Indonesische Archipel: van Soa-organisatie en vierdeling: een studie van traditionale samenleving en cultuur in Indonesie (Disertasi PhD, Universiteit Leiden) [2 Jilid].

Katkova, Irina R. (2011). The cultural crossroads: St. Petersburg, Batavia, Amsterdam. The [IIAS] Newsletter, No. 58/Autumn/Winter, 10.

Kielstra, E. B. (1908). Het Sultanaat van Boeton. [overdruk uit] Onze Eeuw 8(1), $452-472$.

La Niampe. (1999). Nasihat Haji Abdul Ganiu kepada Sultan Laode Muhammad Idrus Qaimuddin: Analisis berdasarkan naskah Kabanti "Ajonga Inda Malusa". Kertas kerja Simposium Internasional Pernaskahan Nusantara III, 12 - 13 Oktober 1999].

Liebner, Horst. H. (2007). Sebuah manuskrip Belanda mengenai kemalangan armada VOC di Pulau Kabaena, Mac - Mei 1650. Jurnal Sari, 25, 51 - 83.

Ligvoet, A. (1878). Beschrijving en geschiedenis van Boeton. Bijdragen tot de Taal-, Land-en Volkenkunde, 26(1), 1 - 112. 
Mourik, Bernardus. (1750). De schandere Hollandsche koop-handelaar, onderwyzende veele zaaken en geheimen nut, gemak en voorzetting van den koophandel. Amsterdam: Bernadus Mourik.

Mourik, Bernardus. (c.1752). Twee-Rampspoedige Zee-reyzen, den eenen gedaan door ...Capitein Morin, met een Fransch Oost-Indisch Compagnie-schip, genaam Le Prince, behelzende een verhaal...op woensdag den 26 April 1752; den anderen met hel Hollandsch Oost-Indische Compagnie schip, genaam Rustenwerk, zynde ten anker leggende, in de Straat en voor het eiland Boeton, door de Mooren en Bokkaneezen, inwoonderen van dat eiland...jammerlyk vermoord geworden enz,; op woensdag den 28 juny 1752. Amsterdam: Bernardus Mourik.

Nolde, Lance. (2015). Strange people. The [IIAS] Newsletter, No.70/Spring, 6 7.

Nurhayati. (2003). Sistem pemerintahan Kesultanan Buton pada masa kepemimpinan Dayanu Ikhsanuddin (Tesis Master Universitas Gadjah Mada, Yogyakarta).

Parthesius, Robert. (2010). Dutch ships in tropical waters: The development of the Dutch East India Company (VOC) shipping network in Asia, 1595-1660. Amsterdam: Amsterdam University Press.

Schoorl, Pim. (1991). Het 'eeuwige'verbond tussen Buton en de VOC, 1613 1669, dalam: H. J. Poeze dan Pim Schoorl (Eds.), Excursies in Celebes: een bundel bijdragen het afscheid van J. Noorduyn als directeur-secretaris van het Koninklijk Instituut voor Taal-, Land- en Volkenkunde, pp. 21 - 61. Leiden: KITLV Uitgeverij.

Schoorl, J.W., G. Winaya dan Jaap Erkelens. (2003). Masyarakat, sejarah dan budaya Butoni. Jakarta: Penerbit Djambatan.

Shellabear, W.G. (1898). An account of some of the oldest Malay MSS. Now extant. Journal of the Straits Branch of the Royal Asiatic Society 31, 107 - 151.

Suryadi, S. (2007a). Warkah-warkah Sultan Buton Muhyiuddin Abdul Gafur kepada Kompeni Belanda, koleksi Univrsiteitsbibliotheek Leiden. Jurnal Sari 25, $187-239$.

Suryadi, S. (2007b). Surat-surat Sultan Buton Dayyan Asraruddin dan Kaimuddin I, koleksi Univrsiteitsbibliotheek Leiden, Belanda. Jurnal Humaniora 19(3), $284-301$.

Suryadi, S. (2010). Dua pucuk surat Kerajaan Buton dari abad ke-17: Kandungan isi dan konteks sejarah. Jurnal Filologi Melayu 17, 123 - 148.

Suryadi, S. (2015). A linguistic kaleidoscope of the Malay letter: The case of the eighteenth century official letters from the Sultanate of Buton. Wacana: Jurnal Ilmu Pengetahuan Budaya 16(2), 304 - 338.

Susanto Zuhdi, G. A. Ohorella, dan M. Said D. (1995). Kerajaan tradisional Sulawesi Tenggara: Kesultanan Buton. Jakarta: Departemen Pendidikan dan Kebudayaan RI. 
Susanto Zuhdi. (2010). Sejarah Buton yang terabaikan: Labu Rope Labu Wana. Jakarta: Rajawali Press \& Yayasan Kebudayaan Masyarakat Buton.

Susanto Zuhdi. 2015. Perang Buton vs Kompeni-Belanda: mengenang kepahlawanan La Karambau. Jakarta: Komunitas Bambu.

Sutherland, Heather. (2001). The Makassar Malays: adaptation and identity, c. 1660 - 1790. Journal of Southeast Asian Studies, 32(3), 397 - 421.

Sutherland, Heather. 2011. Whose Makassar?: claiming space in a segmented city. Comparative Studies in Society and History, 53(04), 791 - 826.

Received: 6 Mac 2018

Accepted: 28 November 2018 


\section{LAMPIRAN I}

\section{Contoh Transliterasi Jawi-Rumi EAP212/6/3}

Halaman 1

Qauluhu al-haqq1,

Bahawa, Paduka Tuan Heer Gurnadur dan segala Rat2 berkirim warkat al-ikhlas dimengaruniakan /1/

dengan tabit3 yang amat banyak serta daripada hati yang suci lagi hening jernih di-wamla4-kan kerana Allah subhanahu wa taala./2/

Maka datang terletak kepada hadirat yang karim Paduka syaudarah iaitu Sri Sultan Azimuddin yang mempunyai tahta /3/

Kerajaan Buton serta dengan segala wazir menteri2nya dan orang besar2nya sekalian di dalam tanah Negeri Buton /4/

yang kami harap senantiasa ia di dalam sehat dan 'afiat dengan sejahteranya, amin ya rabbal alamin $/ 5 /$

Waba'dahu adapun kemudian dari itu bahawa Paduka Tuan Heer Gurnadur dan segala Rat di tanah /6/

Mengkasar bermaklumkan kepada Paduka syaudarah iaitu Sri Sultan yang mempunyai tahta kerajaan tanah Negeri Buton /7/

dan kepada segala wazir menteri2nya serta orang besar2nya sekalian akan hal kepada tujuh belas hari bulan November /8/

tahun dahulu, maka datang kemari utusan kamu itu yang bernama syahbandar yakni Raja Kamilanta nama dirinya Ja'far $/ 9$

serta dengan dua orang menteri yang bernama Menteri Gamad dan Menteri Katapi dan empat orang pengalasan yang bernama /10/

Gamad dan Katapi, Jawah, Litangkawuk serta dua orang juru bahasa di dalam lima buah perahu itu. Maka kami sekalian /11/ 
Warkah EAP212/6/3

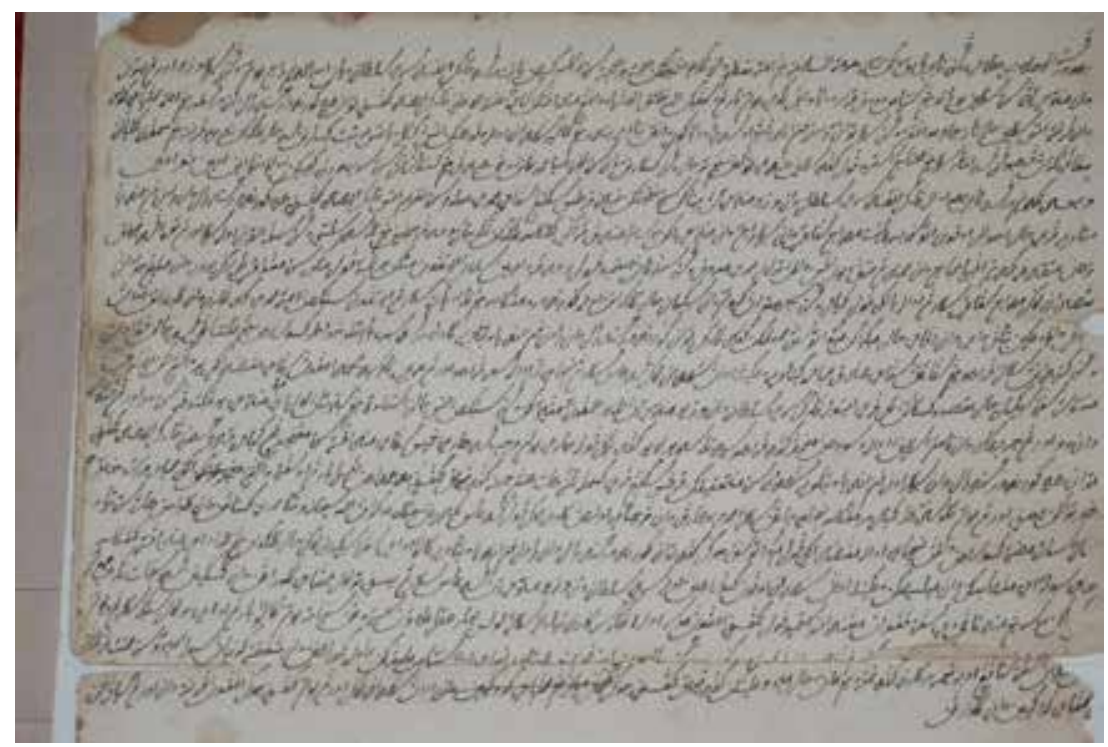

Warkah kedua yang berbeza (halaman 4) yang terkandung dalam EAP212/6/3: Warkah Sultan Dayan Asraruddin kepada Kompeni.

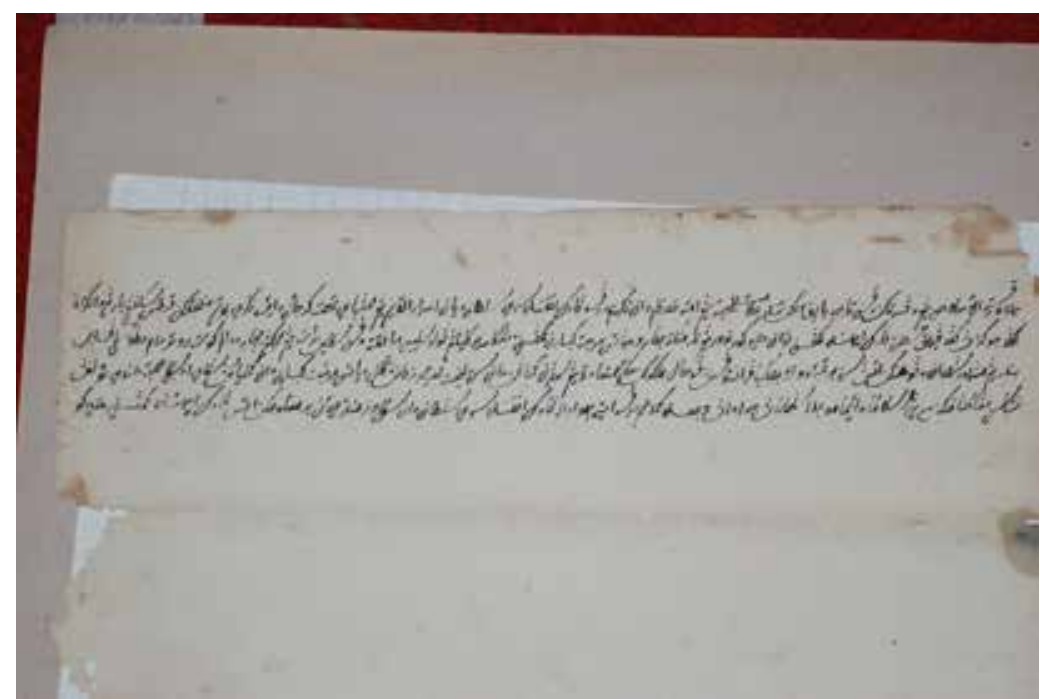

Warkah ketiga (halaman 15) yang terkandung dalam EAP212/6/3: Warkah Sultan Dayan Asraruddin kepada Kompeni. 